\title{
The early Pleistocene whale-fall community of Bargiano (Umbria, Central Italy): Paleoecological insights from benthic foraminifera and brachyuran crabs
}

\author{
Angela Baldanza, Roberto Bizzarri, Federico Famiani, Alessandro Garassino, \\ Giovanni Pasini, Marco Cherin, and Francesco Rosatini
}

\begin{abstract}
New insights into communities of benthic foraminifera and decapods, associated with whale-fall events (WFE) in a relatively shallow sea environment, are reported here for the first time from the early Pleistocene of Bargiano (southwestern Umbria, Italy). The inferred paleodepth of these WFEs is not greater than $100-150 \mathrm{~m}$ and, on the basis of more general stratigraphic data, took place over an estimated period of about 50,000 years. The foraminifera assemblages associated with these WFEs are low in number of planktonic and benthic taxa, and six benthic species dominate: the shallow infaunal species Bigenerina nodosaria, Bannerella gibbosa, Marginulinopsis costata, and Vaginulina cf. V. striatissima, along with the epifaunal species Lenticulina calcar and Siphotextularia concava. Because these opportunistic species respond to shortterm favorable conditions by increasing in number and maintaining stable populations, the presence of high numbers of individuals of these species in association with three recognized WFEs provides evidence that a nutrient-rich environment favored their proliferation. The occurrence of previously unreported benthic foraminifera taxa (across the three WFEs), along with the presence of the crab species Albaidaplax ispalensis (Goneplacidae) and Chlinocephalus demissifrons (Euryplacidae) (in at least one WFE), offer new insights into shallow sea whale-fall fossil communities.
\end{abstract}

Angela Baldanza (corresponding author), Department of Physics and Geology, University of Perugia, Via A. Pascoli - I-06123 Perugia, Italy, angela.baldanza@unipg.it

Roberto Bizzarri, Department of Physics and Geology, University of Perugia, Via A. Pascoli - I-06123

Perugia, Italy, roberto.bizzarri@libero.it

Federico Famiani, Paleontological Museum - Mount Subasio Regional Park, Loc. Cà Piombino - I-

06081Assisi, Perugia, Italy. federico.famiani@gmail.com

Alessandro Garassino, Natural History Museum, Paleontology Department, Corso Venezia 55 - I-20121

Milan, Italy. alegarassino@gmail.com

Baldanza, Angela, Bizzarri, Roberto, Famiani, Federico, Garassino, Alessandro, Pasini, Giovanni, Cherin, Marco, and Rosatini, Francesco. 2018. The early Pleistocene whale-fall community of Bargiano (Umbria, Central Italy): Paleoecological insights from benthic foraminifera and brachyuran crabs. Palaeontologia Electronica 21.1.11A 1-27. https://doi.org/10.26879/779 palaeo-electronica.org/content/2018/2148-whale-fall-paleo-community 
Giovanni Pasini, Via Alessandro Volta 16 - I-22070 Appiano Gentile (Como), Italy. juanaldopasini@tiscali.it Marco Cherin, Department of Physics and Geology, University of Perugia, Via A. Pascoli - I-06123

Perugia, Italy, marco.cherin@unipg.it

Francesco Rosatini, Via Strada di San Giacomo 1/D - I-06132 Fontignano (Perugia), Italy. f.rosatini@gmail.com

Keywords: Benthic communities; Decapoda; Whale-fall events; Paleoecology; Calabrian; PaleoMediterranean Sea

Submission: 2 May 2017 Acceptance: 24 March 2018

\section{INTRODUCTION}

The carcasses of great whales (including both baleen and sperm whales) are the largest form of detritus to collect on the sea floor. Dead whales, whose bodies consist largely of proteins and lipids, typically sink to the sea floor where they serve as an enormous, temporary source of organic enrichment: a forty-ton gray whale, for instance, supplies approximately two million g C, equivalent to $>2000$ years of background $C$ flux in the area beneath and around the carcass (Smith, 2006).

Over the last two decades, research into modern and fossil whale-fall events (WFE) has increased considerably, providing new insights on whale-fall ecosystems (Smith et al., 2002, 2015; Smith and Baco, 2003; Goffredi et al., 2004, 2008; Smith, 2006; Dominici et al., 2009; Danise et al., 2010, 2014; Higgs et al., 2010, 2012; Lundsten et al., 2010a, 2010b; Danise and Dominici, 2014; Roman et al., 2014; Taboada et al., 2016).

A whale carcass on a seabed provides a massive feast for other organisms, and sea floor feeding and dismantling of a carcass by macro- and micro-scavengers and carnivores has been observed and studied in the Pacific and Atlantic Oceans, deep-sea Antarctic, and other internal seas (Fujioka et al., 1993; Bennett et al., 1994; Wada et al., 1994; Smith et al., 2002, 2015; Smith and Baco, 2003; Goffredi et al., 2004; Fujiwara et al., 2007; Lundsten et al., 2010a, 2010b; Amon et al., 2013; Linse et al. 2014; Smith et al., 2014; Sumida et al., 2016). The area around a decaying carcass becomes a specialized, if temporary ecosystem rich in organic matter and sulfides, a kind of "habitat island" on the seafloor (Smith et al., 2015).

Great-whale carcasses (baleen and sperm whales) are able to support both a sequence of heterotrophic and chemosynthetic microbial assemblages and metazoan communities in the energy-poor deep sea, all of which pass through a series of three principle and overlapping ecological stages (Smith et al., 2002, 2015; Smith and Baco,
2003; Smith, 2006). Each stage is characterized by a diverse food chain and diverse fauna, with differing species associated with ocean or internal-sea WFEs. The whale-fall ecosystem supports the development of a characteristic fauna, which reaches and maintains high species abundance for decades. Thus, many new species and evolutionary novelties have been recorded, including boneeating annelid worms, gastropods, a variety of grazers on sulphur bacteria, in addition to typical mollusk and serpulid assemblages (Smith et al., 2015, and references therein).

Research on WFEs is commonly focused on assemblages of microbes or of mollusks and other metazoans (Smith et al., 2015, and references therein); less is known, conversely, about benthic foraminifera and decapods associated with whale falls (see Appendix 1). If the presence of decapods (among other crustaceans such as amphipods, isopods, and rare barnacles and ostracods) is already documented, however, data about benthic foraminifera are rarely reported (Fujioka et al., 1993; Wada, 1993; Wada et al., 1994; Naganuma et al., 1996; Gooday and Rathburn, 1999; Rathburn et al., 2003; see also Geist, 2010). The modern-day WFEs that have been analyzed to date usually involve events at great depths; in those environments, benthic foraminifera assemblages were generally scarce while typical deep-ocean species that tolerate low oxygen content were noted (Gooday and Rathburn, 1999).

Research on fossil whale falls from the Eocene to the Pliocene (see Appendix 1) also contributed to descriptions of faunal assemblages (mainly invertebrates) in shelf to bathyal paleoenvironments (Lancaster, 1986; Amano and Little, 2005; Nesbit, 2005; Amano et al., 2007; Dominici et al., 2009; Danise et al., 2010, 2014). Among these findings, only Amano and Little (2005) and Amano et al. (2007) reported data about benthic foraminifera assemblages associated with fossil WFEs. 
The unusual assemblage of benthic foraminifera and the decapod fauna recovered at the Bargiano site (southwestern Umbria, central Italy), both of which are related to the presence of organic matter in proximity to a whale carcass, represent a novelty for fossil whale-fall events, particularly for the Quaternary.

The silty clayey marine sediments of the early Pleistocene Bargiano site (southwestern Umbria, central Italy) are already known in the paleontological record for their exceptional and unusual preservation of Ambergrisichnus alleronae fossil cololites. Baldanza et al. (2013) and Monaco et al. (2014) described several WFEs preserved at Bargiano (and more generally in the Allerona area) that appear to have occurred over a relatively short span of time.

Paleontological excavations in the Allerona area during 2003, 2008, and 2016 yielded three partial skeletons of baleen whales. Although fossils of these marine mammals are abundant in other areas of the Italian peninsula (e.g., Tuscany, Piedmont, Emilia Romagna, and Salento; see Bianucci, 2014), the Allerona finds represented the first reports of cetaceans in Umbria. The specimens are still under preparation and study, but preliminary observations allow us to refer them to at least two different mysticete families: Balaenidae and Balaeonopteridae. These data add to the massive presence of sperm whales, documented by the occurrence of Ambergrisichnus alleronae (Baldanza et al., 2013; Monaco et al., 2014). Indeed, the entire Allerona area, not only the well-known Bargiano site, represents a sea floor paleoenvironment deeply conditioned by WFEs and by the dispersion of decayed cetacean remains. The Bargiano scenario reported here permits us to speculate on the original environmental scenario and on the paleoecological relationships among and behavior of the marine invertebrates collected within and around the whale falls.

The benthic infaunal foraminifers collected at Bargiano (Appendices 2 and 3), preliminarily reported by Rosatini (2016), nonetheless appear dissimilar to those reported from fossil or modernday WFEs. In addition, decapod specimens, located around or between the bones of a large cetacean, were recovered (for a detailed analysis, see Appendices 4 and 5 ), including a new species of brachyuran crab (Asthenognatus alleronensis), previously unknown from the Pleistocene of the Mediterranean area and recently described by Pasini et al. (2017).

\section{GEOLOGICAL SETTING}

The study site (Figure 1.1) lies close to the town of Allerona and is part of the South Valdichiana Basin. During the early Pleistocene, the basin accommodated a relatively shallow marine environment (on the order of a maximum of $100-150$ $\mathrm{m})$. The geological, sedimentological, and stratigraphic description can be found in Baldanza et al. (2013) and Monaco et al. (2014).

In the Bargiano section, massive to thinly-laminated offshore marine deposits crop out, ranging from clay to clayey silt to silty clay (Figure 1.2). Calcareous nannofossil and foraminifer assemblages from this site indicate an early Pleistocene (Calabrian) age (CNPI8 Zone sensu Backman et al., 2012; MPLe1 Zone sensu laccarino and Premoli Silva, 2007), and a relatively shallow offshore environment (about 100-150 m). The recent recovery of a baleen whale skeleton (Figure 1.3) has allowed us to complete a vertical stratigraphic profile of the site.

A section about $2 \mathrm{~m}$ thick (WS), measured from some $70 \mathrm{~cm}$ above the skeletal remains to about $1 \mathrm{~m}$ below, was described (Figures 1.2-3, 2). Within that section, three main decapod horizons were recognized, although we also noted the irregular occurrence of decapods throughout the entire section (Figure 2). In addition, four shorter sections (S1, S2, S3, and S4) were described and sampled at increasing distances from the whale skeleton in order to investigate lateral and vertical variations in microfossil distribution (Figures 1.2, 2). Because of the slight north-eastern inclination of the clay beds, these five sections permitted the reconstruction of a $2.8 \mathrm{~m}$-thick composite stratigraphic section (Figure 2). Finally, a $30 \mathrm{~cm}$-thick section was described in the main cololites field (CFT: Cololite Field Trench section, Figures 1.2, 2), about $50 \mathrm{~m}$ northeast of and $4 \mathrm{~m}$ stratigraphically above the cetacean skeleton. Such interpolation was allowed to recognize a total of 25 irregularly-spaced stratigraphic levels (Figure 2), 22 of which lie in the main section with three in the CFT section.

\section{MATERIAL AND METHODS}

Forty samples were collected from the 25 measured levels across the six sections (Figures $1.2,2)$. About $200 \mathrm{~g}$ of sediment from each sample were processed for micropaleontological analyses. The sediment was washed with hydrogen peroxide and water then sieved through a $63 \mu \mathrm{m}$ mesh to obtain the residue. Residues generally did not exceed $2 \mathrm{~g}$. The entire washed residue was 

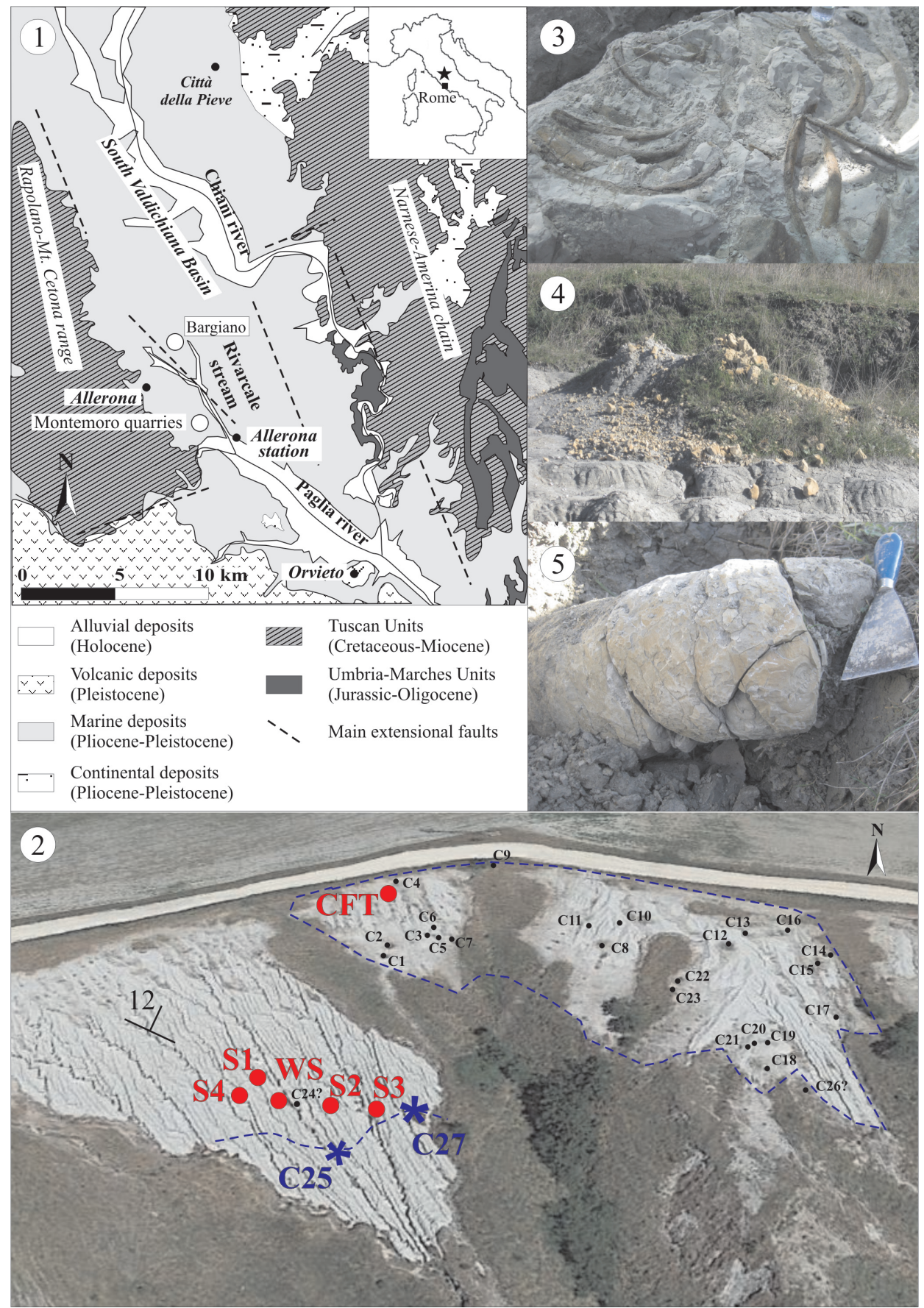

FIGURE 1. Bargiano site. 1. Simplified geological sketch for the study area (redrawn after Monaco et al., 2014 ). 2. Position of stratigraphic sections reported in Figure 2. Numbers and black dots refer to the position of Ambergrisichnus alleronae cololites (after Monaco et al., 2014). WS=Whale section; S1-S4=additional sections; C27=Section near Cololite \#27; C25=Section near Cololite \#25; CFT=Cololite Field Trench. 3. Detail of whale bones during June 2016 excavation. 4. Cololite \#27. 5. Close-up of Cololite \#25.

observed under a stereomicroscope (Nissho optical, TZ240) for semi-quantitative analysis of total and relative abundances and species diversity of foraminifera. Selected benthic foraminifera specimens were analyzed using a scanning electron microscope (SEM - Philips, 515) for the identification of morphological characteristics.

Of the twenty decapod specimens recovered, only the seven best-preserved, partially in life position and with exposed dorsal and ventral views, were considered. The specimens, embedded in 


\begin{tabular}{|c|c|c|c|c|}
\hline 总 & Age & $\sum_{\infty}^{\infty}$ & 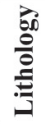 & Bargiano site \\
\hline
\end{tabular}
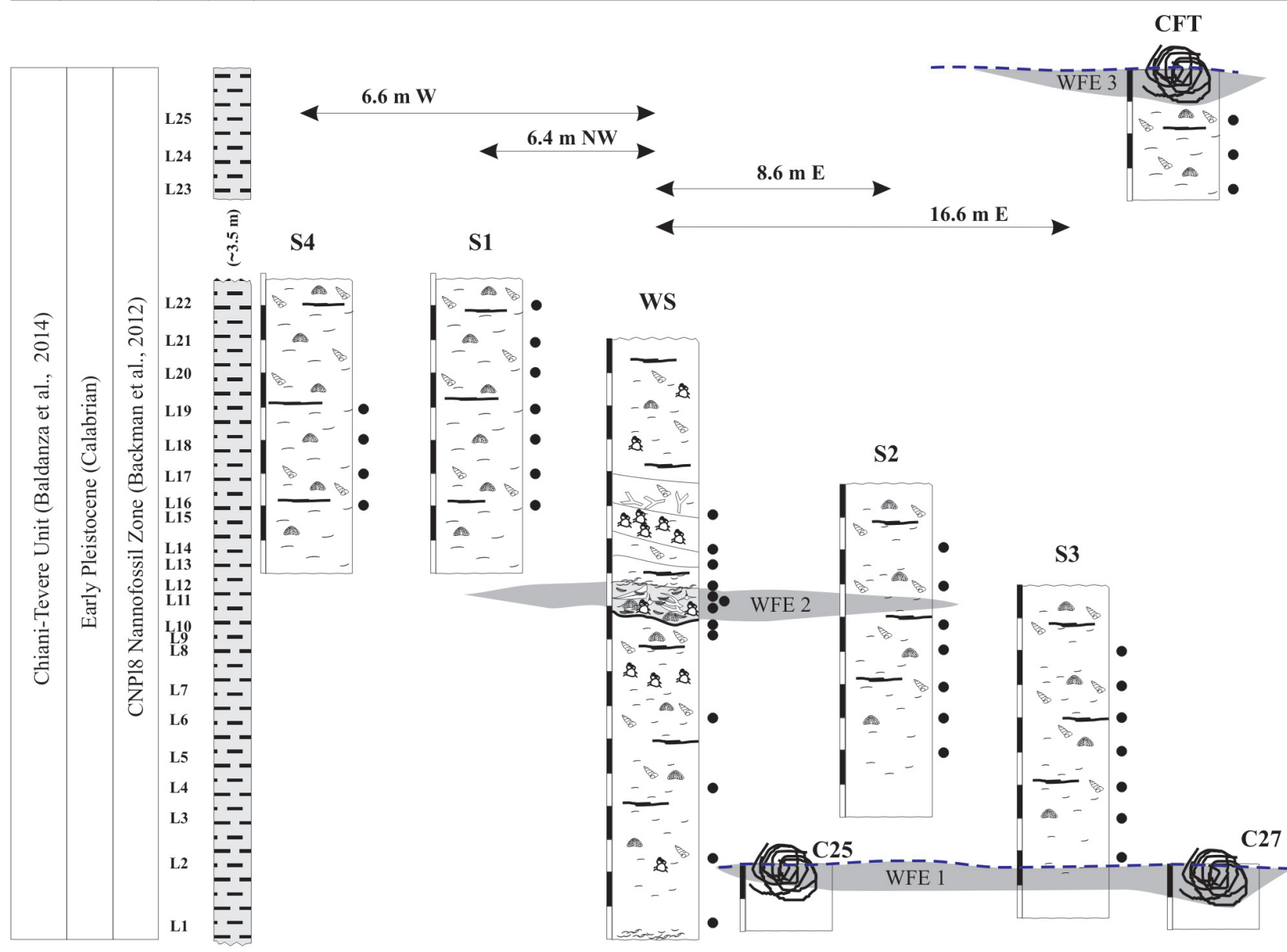

\section{S3}

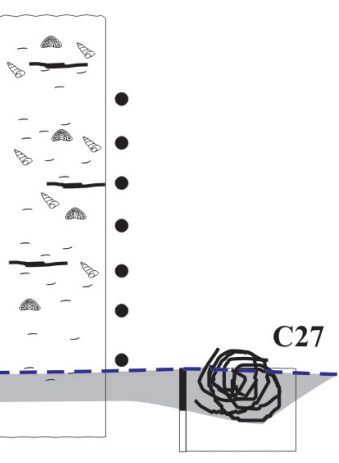

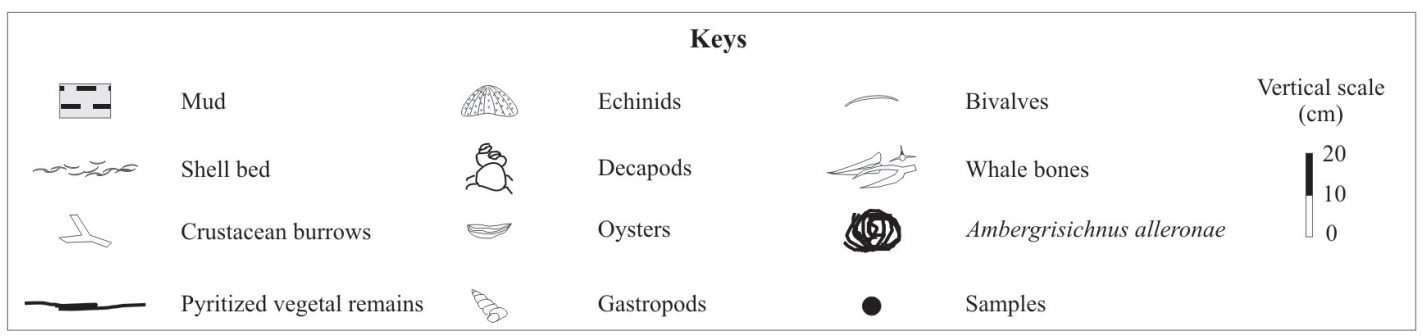

FIGURE 2. Lithostratigraphic sections through the cetacean excavation site at Bargiano. Lateral distances are not to scale. Acronyms for sections are the same as in Figure 1.2. WFE= whale-fall events (1-3).

small blocks of blue-grey clay and covered by a thin patina of yellow-brown iron oxide were carefully prepared and, due to the delicate nature of the fossils and the loose matrix, fixed with polyvinyl acetate for study and preservation. The specimens were labeled with the MUAL (Museo di Allerona) institution code, progressively numbered, catalogued, and stored in the museum.

\section{RESULTS}

Recent field surveys (2015 and 2016) enabled the completion of the preliminary stratigraphic profile of the Bargiano site reported by Monaco et al. (2014). Crude silty clay beds dip more-or-less uniformly north-east across the study area, but local stratification can rarely be recognized because of the presence of three main families of joints (late Pleistocene-Holocene tectonics). 


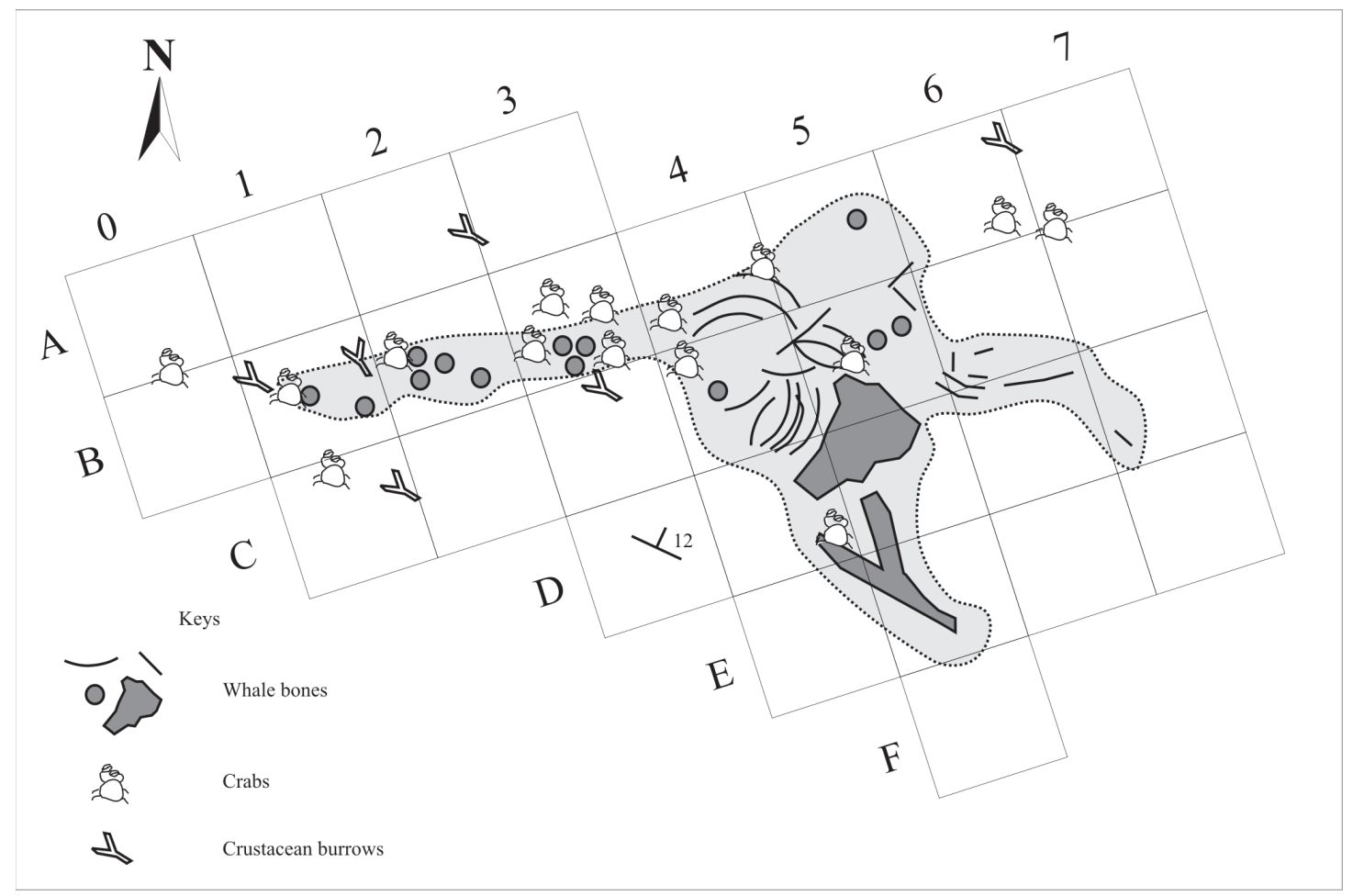

FIGURE 3. Plan view across the cetacean excavation surface, at about $357 \mathrm{~m}$ above sea level, with the original positions of crab specimens collected around and between the whale bones. Each grid section represents one square meter.

With regard to the fossil record, the species of malacofauna at Bargiano are reported in Monaco et al. (2014, table 1), accompanied locally by echinoids, and showed no significant variations through the sections shown in Figure 2, whether vertically or laterally. Decapod crustaceans, together with undescribed thalassinidean and goneplacid burrows (Pasini et al., 2017, p. 69), were highly abundant only within a short radius from the whale bones (Figure 3), while their occurrence in the rest of the composite section was sporadic.

The foraminifera assemblages recovered from all the samples were, in general, depleted in both planktonic and benthic taxa, although relativeabundance values (RA) highlighted the predominance of six epifaunal or shallow infaunal taxa, with the latter type being more common (Figure 4).

\section{Whale-fall Events}

Throughout the section, three main WFE horizons were recognized (Figure 2). They were stratigraphically numbered and named WFEs $1-3$. The lowermost event (WFE 1: Figures 1.2, 2) is characterized by Cololite Horizon \#25 (close to the excavation site; Figures 1.2, 1.5, 2) and \#27 (about 22.5 $\mathrm{m}$ east; Figures 1.2, 1.4, 2). WFE 2 corresponds to the baleen whale skeleton horizon (Figures 1.3, 2); fragments of a cololite (Cololite \#24) were noted close to the whale remains, but the cololite's original position was not found. Finally, WFE 3 is the main area in which Ambergrisichnus alleronae fossils were found (Figures 1.2, 2), as described by Baldanza et al. (2013) and Monaco et al. (2014). The CFT section was measured and sampled close to Cololite \#4 (Figure 1.2). These WFEs are in addition to the three (or four) events already noted throughout the Montemoro section described by Monaco et al. (2014, figure 1.2).

\section{Planktonic Foraminifera}

Across the six sections, planktonic foraminifera were largely comparable to those reported by Monaco et al. (2014). The assemblages in both the Bargiano and Montemoro sections included very few taxa (Globigerinoides ruber, Globigerinoides sacculifer, Globigerina bulloides, Globorotalia inflata, Globigerina cariacoensis, and Orbulina universa), and abundance was low. Turborotalita quinqueloba sporadically occurred in low frequencies. Plankton reached common values in only a few samples: at the top of S4, in samples 3-7 of S1, at the top of WS, and at the tops of S3 and S2 sec- 


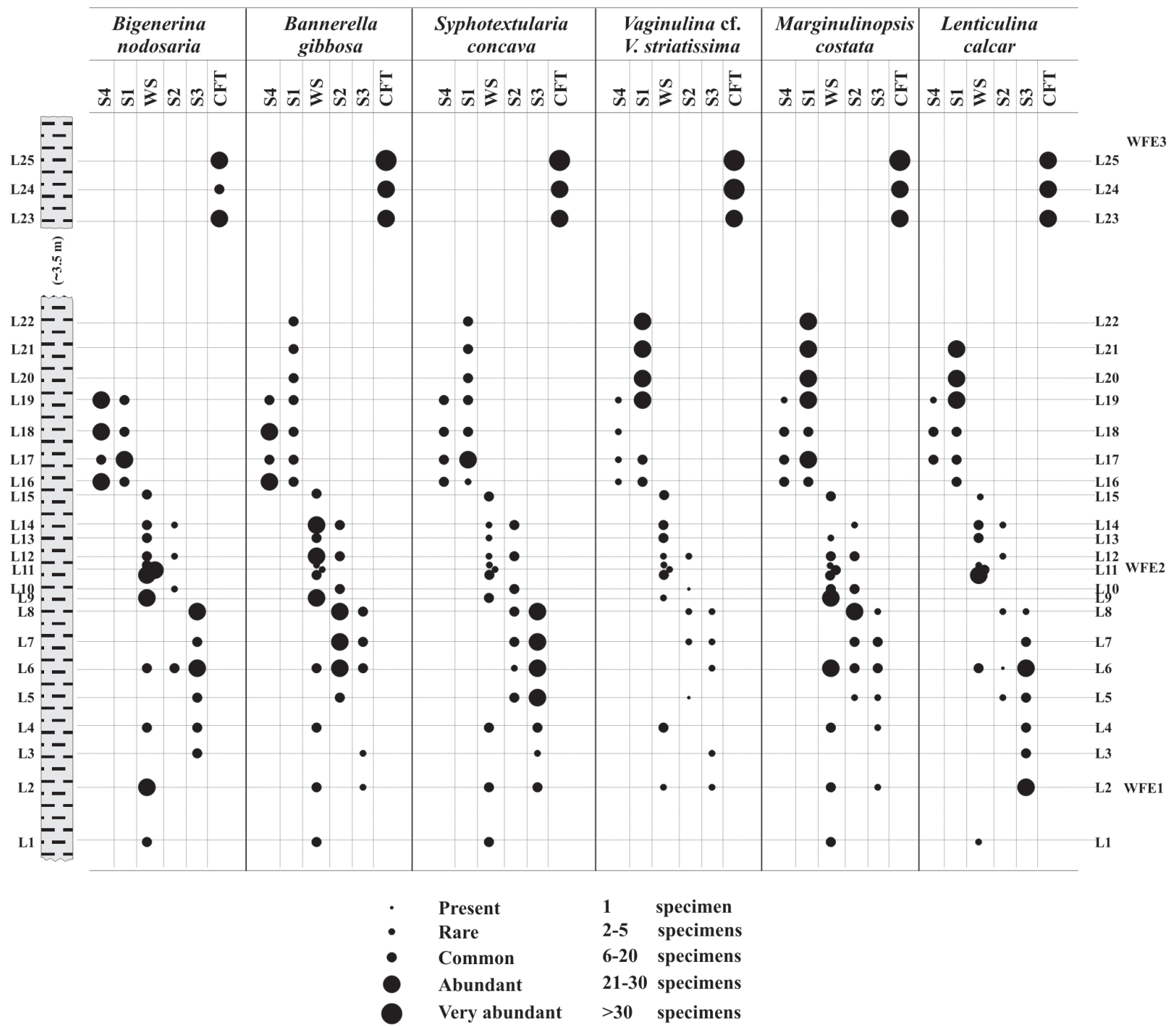

FIGURE 4. Distribution of abundances of the six selected benthic taxa, indicative of nutrient increase related to WFEs.

tions (see Figure 2). In the CFT section (Figure 2), planktonic foraminifera were common everywhere, with $O$. universa abundant at the base.

\section{Benthic Foraminifera}

Preliminary data reported by Monaco et al. (2014) indicated that epifaunal and shallow infaunal foraminifera taxa were predominant at the Bargiano site, confirming the abundance of degraded organic matter derived from WFEs.

General observations. The assemblages were very low in number of taxa, and relative abundances (RA) were likewise low, except in the case of Bigenerina nodosaria, Bannerella gibbosa, Marginulinopsis costata, Lenticulina calcar, Siphotextularia concava, and Vaginulina cf. V. striatissima.
The benthic taxa showed low species-diversity values (SD), varying from 17 to 1 as a function of distance from the whale skeleton or cololites. Lower SD values were observed in the WS section. SD values were highest, particularly in the lowermost levels, in sections S1 and S4, as well as in S2 and S3, located at varying distances from the whale skeleton (Figures 1,2), while the WS section showed medium SD values (from 8 to 6 ). In the CFT section, the assemblages were always poor, whereas the SD, which included planktonic taxa, varied from 20 to 15 .

The taxa are epifaunal and shallow infaunal. Detritivores are most common among the epifauna (Lenticulina, Cancris, Cassidulina, Siphotextularia, Gyroidina, and Hyalinea), with Bannerella, Fursen- 
koina, Bolivina, Nonionella, Melonis, Bulimina, and Elphidium predominant among shallow infauna. Generally subordinate genera include the herbivorous epifaunal Martinottiella, Quinqueloculina, Lobatula, and Asterigerinata; the shallow infaunal Ammonia; the epifaunal suspension feeders Heterolepa and Lobatula; and the shallow infaunal omnivore Bigenerina.

Dominant taxa. Representatives of Families Textulariidae, Vaginulinidae, and Eggerellidae (see Appendix 2) reached considerable statistical frequencies in sediments close to skeletal remains (Figures 2, 4) and predominated the highly depleted assemblages (Figures 4, 5, 6). As reported by Murray (2006), the preponderance of foraminifera living in fine-grained sediment below the photic zone are infaunal, feed on detritus or bacteria, and are abundant in the uppermost 1-2 $\mathrm{cm}$ of sediment. Textulariidae, in particular, are passive detritivores (detrital and bacterial scavengers), while Vaginulinidae are stationary infaunal deposit feeders (Murray, 1991). The highest RA values (varying from common to abundant to very abundant; see Figure 4) in all the sections were reached by the shallow infaunal taxa Bigenerina nodosaria, Siphotextularia concava (Textulariidae), and Bannerella gibbosa (Eggerellidae) and the Family Vaginulinidae species, Marginulinopsis costata, Vaginulina cf. V. striatissima (both shallow infaunal species) and Lenticulina calcar (epifaunal). Moreover, when the SD values were very low (in the WS section, for example), only these six taxa occur in assemblages. As Figure 4 makes clear, the RA of the six taxa showed varying trends across the 25 levels and the three WFEs.

In all sections, unexpectedly, Bigenerina nodosaria was the dominant taxon: its RA varied from common to abundant, with the exception of the S2 section where it was common at the base and decreased upwards to rare (Figures 4, 5.1-3). Much is known about the lifestyle and ecology of $B$. nodosaria. Mojtahid et al. (2010), for example, in research at a 320-m deep station in Biscay Bay (NE Atlantic) under eutrophic conditions, identified it as a shallow infaunal species with a penetration depth of from 0.7 to $2.0 \mathrm{~mm}$; the authors also characterized $B$. nodosaria as a common taxon all around the Mediterranean in circalittoral and upper bathyal muds (Sgarella and Moncharmont-Zei, 1993). de Stigter et al. (1998) found B. nodosaria from the shelf/upper slope to the middle slope in the Southern Adriatic Sea, and Kaminski et al. (2002) and Chendes et al. (2004) reported B. nodosaria in large numbers below $140 \mathrm{~m}$ in the
Marmara Sea, with a critical point at about $220 \mathrm{~m}$. Fontanier et al. (2002) identified B. nodosaria as a eutrophic species, well developed in environments where there was high marine productivity. Finally, Gross (2000) observed an elevated mean migration speed for this taxon during food-enrichment experiments.

The presence of Bigenerina nodosaria in high numbers across Sections WS, S1, and S4 (the latter two are located about $6.5 \mathrm{~m}$ from the whale skeleton, denoted WFE 2) suggests that the habitat was ideal for its omnivorous lifestyle, and that the increase in organic matter in sediments below the carcass was not a barrier to development. It is worth noting that $B$. nodosaria became rare in Section $\mathrm{S} 2$, probably because, at $8.5 \mathrm{~m}$ from the skeleton, the content of organic matter in the sediments was considerably reduced. In Section S3, B. nodosaria was again abundant and common but, in this scenario, the most likely source of nutrients was WFE 1 (Figures 1,2), as documented by the presence of Cololite \#27 about 6 m west of Section S3. The occurrence of $B$. nodosaria in highly depleted assemblages, such as those found in this study, is additional convincing evidence for the opportunistic character of this species and its capacity to migrate to nutrient-rich areas ideal for development and reproduction.

A similar behavior seems to characterize Bannerella gibbosa (Figures 4, 5.8-9), a shallow infauna and detritivorous species that occurs abundantly in Section S4 and which is common and abundant in Sections WS and S2 (in levels close to the whale skeleton). In Section S3, B. gibbosa is rare, becoming common only in the uppermost samples. The species appears to have an affinity for sediments rich in abundant but likely low quality organic matter, though its behavior is not known in detail. The other representative of the Textulariidae, the epifaunal detritivore Siphotextularia concava (Figures 4, 5.10-15), was common in Sections S4 and S1, except in one basal sample of S1 in which it was abundant. In Section WS, it was generally rare to common, constantly common in Section S2, and very abundant in Section S3. This species also shows a high affinity for sediments rich in organic matter but does not seem to tolerate high organic flux, as suggested by its rarity in sediments proximate to skeletal remains. An epifaunal lifestyle probably affected the development of $S$. concava, and it was likely unable to develop if nutrients at the sediment-water interface were overloaded. 

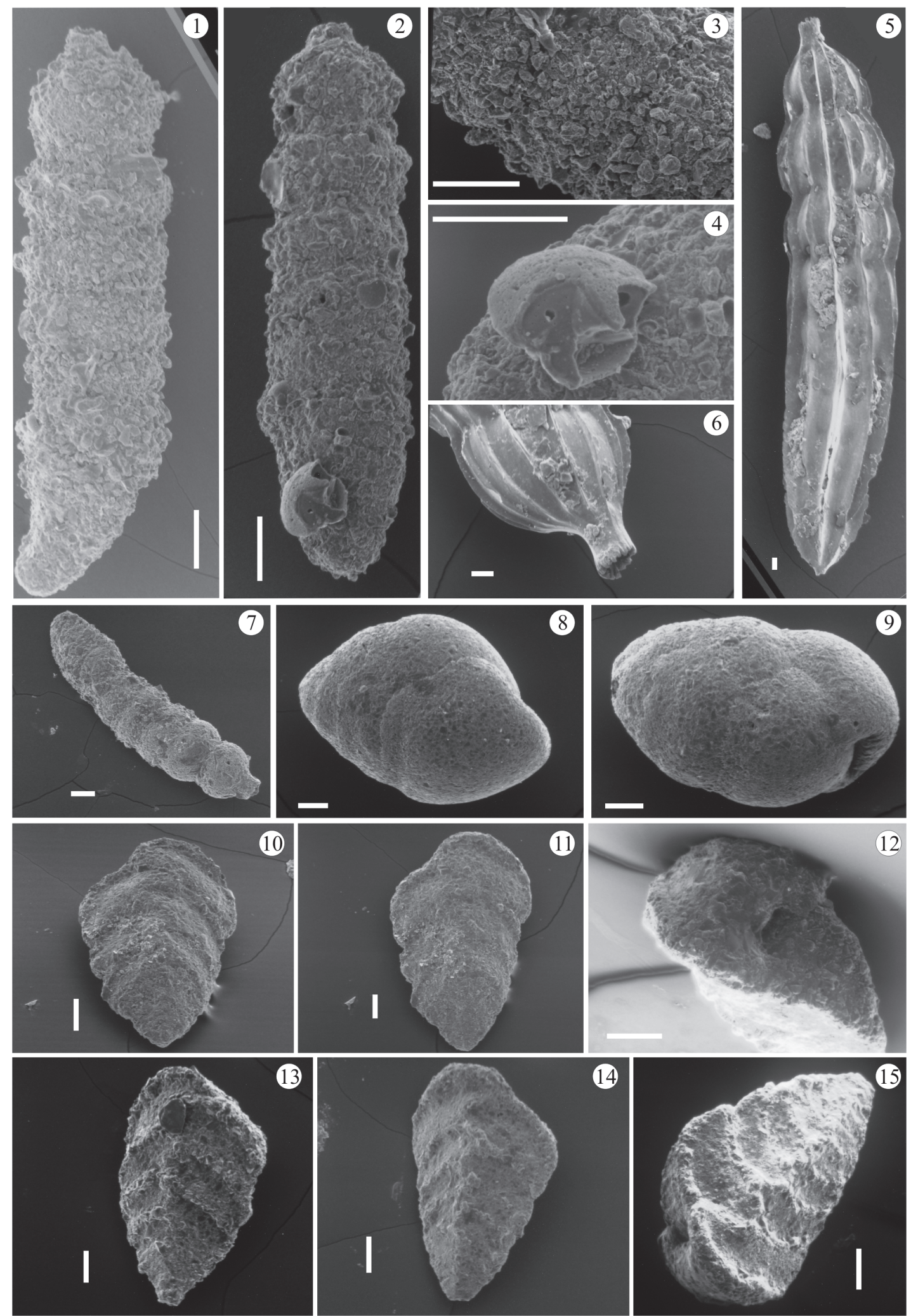

FIGURE 5. Benthic foraminifer taxa characteristic of the Bargiano sections (scale bar equals $0.1 \mathrm{~mm}$ ). 1-4, 7. Bigenerina nodosaria. 3. Detail of surface test of $B$. nodosaria. 4. Fragment of porcellanaceous foraminifer glued in $B$. nodosaria test. 5, 6. Marginulinopsis costata. 6. Detail of aperture. 8-9. Bannerella gibbosa. 10-12. Siphotextularia concava. 12. Detail of aperture; note the thin lip surrounding the aperture. 13-15. Siphotextularia concava, specimens with marked and prominent chamber rims. 


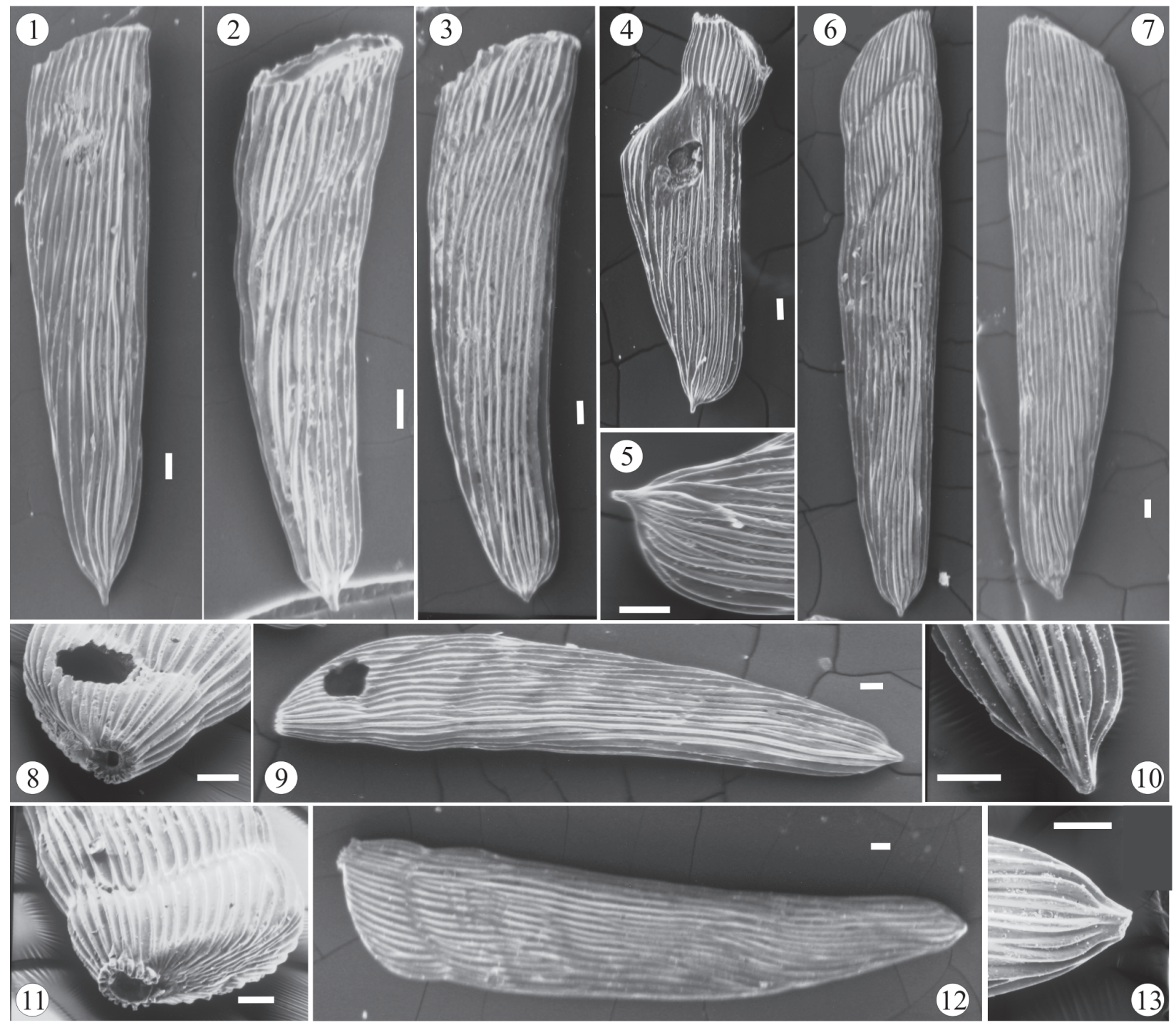

FIGURE 6. Vaginulina cf. Vaginulina striatissima. Variations in test morphologies with details of spines, costae, and buccal apertures (scale bar=0.1 mm). 1. Specimen from S1 section. 2. Specimen from S2 section. 3. Specimen from S3 section. 4-5. Specimens from S4 section. 6-7. Specimens from CFT section. 8-10. Specimen from CFT section. 8. Detail of aperture. 9. Test showing evidence of predation (large opening in the final chamber). 10. Detail of basal spine. 11-13. Specimen from CFT section. 11. Detail of aperture. 13. Detail of basal spine with broken apex.

The stationary infaunal deposit feeder family Vaginulinidae (Murray, 2006) is represented at the Bargiano site by Vaginulina cf. V. striatissima and Marginulinopsis costata (probably shallow infaunal taxa, considering the test morphologies and position of aperture) and Lenticulina calcar (a detritivore epifaunal species that prefers cold water; see Murray, 2006). In particular, V. cf. V. striatissima (Figures 4, 6), until now reported only from Pleistocene clays, shows high frequencies. The Bargiano specimens are covered by well-developed costae and display a prominent basal spine (Figure 6) and are, moreover, very large, ranging $4-5 \mathrm{~mm}$ in length.

The morphology of the test (see Appendix 3 for detailed description and taxonomy notes), which deviates from the characteristics of Vaginulina striatissima (original drawn by Schrodt, 1890, plate 21, figure 9a-b: Ellis and Messina, 19402006), leads us to hypothesize that modifications in the costae and spine of these foraminifera were induced by the soft clay substrate and a high availability of nutrients that stimulated reproduction. The specimens found in the CFT section, compared to those found in sections $\mathrm{S} 1-\mathrm{S} 4$, show differences in 
length of the test and in number of costae (radiating from basal spine to last chamber), which become thinner and more anastomized (Figure 6).

Lenticulina calcar and Marginulinopsis costata (Figures 4, 5.6-5.7) showed similar trends along the 22 lowermost levels, with irregular, very abundant to abundant occurrences between WFE 1 and WFE 2, common abundances (WFE 2, from Levels 12 to 15), and very abundant occurrences above WFE 2 (between Levels 15 and 22).

The RA of Marginulinopsis costata was abundant and common in Section S2; in the WS section, the species was common below and above the skeletal remains, becoming abundant in samples closest to the bones (WFE 2). In Section S1, it was abundant overall and dominated the assemblages whereas, in Section S4, its RA decreased from common to rare in the uppermost sample. The behavior of $M$. costata is not clear: with a shallow infaunal lifestyle, it prefers soft sediments and reaches a large size (over $6 \mathrm{~mm}$ ), evidence that nutrient-rich sediments are an ideal habitat for this opportunistic species.

Lenticulina calcar, an epifaunal detritivore that prefers cold water, showed four peaks of abundances (Figure 4): at the base and top of Section S3 (coinciding with WFE 1), in the WS samples (close to the skeleton remains), and in the last three samples from Section S1. Lenticulina calcar has been reported in several other marine shoreface to offshore deposits in southwestern Umbria, while $M$. costata is a typical inhabitant of offshore deposits (Bizzarri et al., 2015).

Analogous distributions were observed in the CFT section in which benthic communities were dominated by abundant to very abundant Bigenerina nodosaria, Siphotextularia concava, Bannerella gibbosa, Vaginulina striatissima, Marginulinopsis costata, and Lenticulina calcar (Figure 4).

Subsidiary species. Other taxa were also noted, although their abundance was low and their occurrence was irregular across the six sections. Among them, Quinqueloculina seminula was common below and above the bones in the WS section. In Sample 3 of Section S1, species of the Ammonia group (Ammonia parkinsoniana, A. beccarii, A. tepida, A. perlucida) were common, as was Bolivina spathulata and Bulimina spinata. In all samples from S1, Uvigerina mediterranea, a shallow infaunal cold-water detritivore, was common. Conversely, Bulimina marginata was common from Sample 4 to the top of the section.

Few differences were noted in the CFT section, where the epifaunal herbivorous species
Asterigerinata mamilla and the suspension feeders Heterolepa floridana and Lobatula lobatula occur commonly. The species B. spathulata, B. marginata, B. spinata, Cancris auriculus, Cassidulina laevigata, Melonis barleanum, Nonionella turgida, and $U$. mediterranea were rare and sporadic.

This situation is noteworthy because the lifestyles of Ammonia and Bulimina (Murray, 1991), as a shallow infaunal herbivore (Ammonia) and a shallow infaunal detritivore (Bulimina), are linked by similar behavior that leads both species to colonize burrows where they feed upon bacteria on the burrow walls. Jorissen et al. (1992) reported $B$. marginata as an opportunist species found as many as $4 \mathrm{~cm}$ below the surface of the sediment and able to respond to high food availability.

\section{Decapods}

All decapod crustaceans found at the Bargiano site came from the WS section and mainly belonged to two species: Albaidaplax ispalensis Garassino, Pasini and Castro, 2013 and Chlinocephalus demissifrons Ristori, 1886 (Figure 7; see Appendices 4 and 5 for taxonomic descriptions; see also Karasawa and Kato, 2003, and Schweitzer et al., 2010). They were accompanied by the recently described crab Astenognathus alleronensis Pasini, Garassino and De Angeli, 2017 (family Varunidae), the first report of this genus in the Pleistocene worldwide, by fragments of ?Goneplax sp. and Jaxea sp., and by undescribed crustacean burrows (Pasini et al., 2017, p. 69). We note that the Bargiano specimens of $A$. ispalensis were larger both than the type series and other specimens reported from Italy and also bear a poorly distinct and obsolete tooth on the anterolateral margins.

In comparison to Ristori's specimen and the specimen reported by Garassino et al. (2004, p. 275: figures. 15, 16), Chlinocephalus demissifrons from Bargiano showed some variations in the outline of the carapace (which was more elliptic in shape), fewer raised transverse carinae, and ornamentation that was more pitted dorsally and on the $\mathrm{P} 1$. This carapace variability is likely due to growth stages, as has been noted among several extant representatives of the Euryplacidae (Castro and $\mathrm{Ng}, 2010$, p. 6). These differences could also suggest, however, the presence of a local "type" not yet recognized in fossil species or they may reflect small normal variations. In any case, the differences in our opinion are too inconsistent to allow us to describe a new taxon for the Bargiano specimens. 

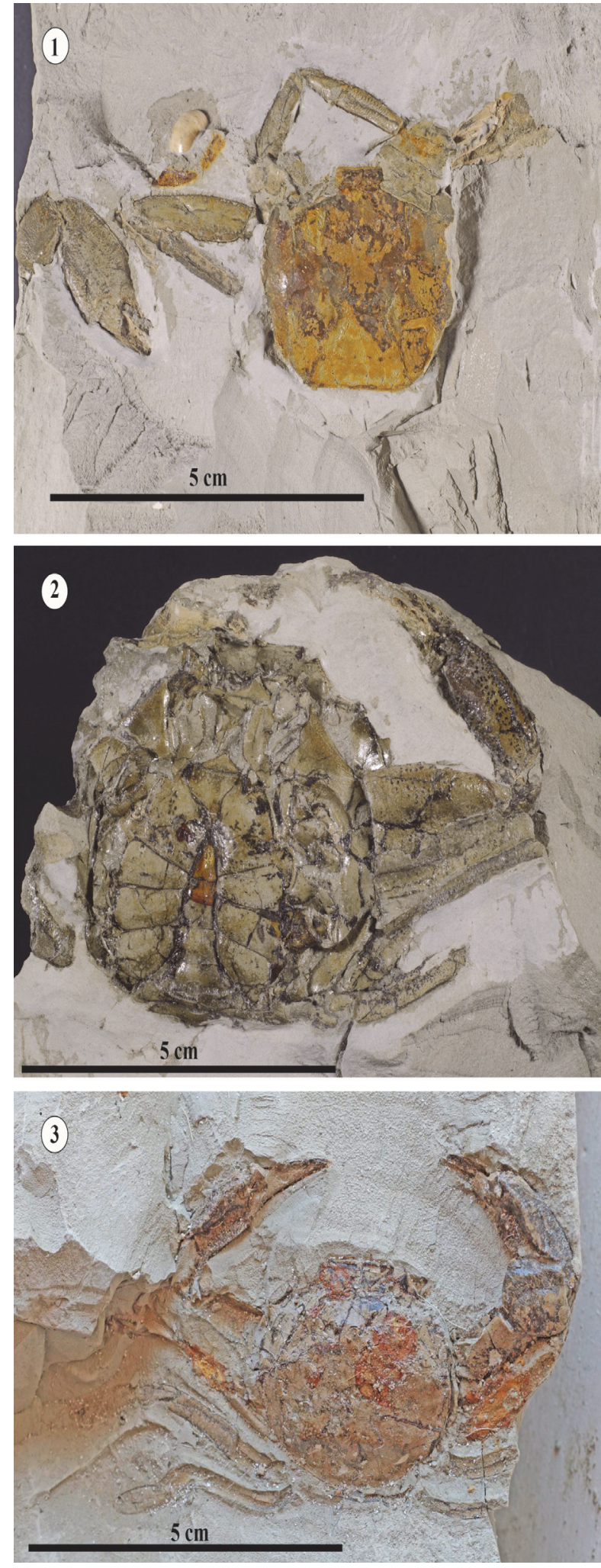

FIGURE 7. Decapod crustaceans from the Bargiano site. 1. Albaidaplax ispalensis Garassino, Pasini and Castro, 2013, MUAL 9. 2. Chlinocephalus demissifrons Ristori, 1886, MUAL 2. 3. Chlinocephalus demissifrons Ristori, 1886, MUAL 10.

\section{DISCUSSION}

The entire Allerona area represents a unique paleoenvironment in which several WFE took place over the span of about one hundred thousand years (Monaco et al., 2014), with a probable increase in WFE frequency in the uppermost sequence. These values, as well as the sedimentation rates reported below, are derived from the general stratigraphic reconstruction at the scale of the basin (Baldanza et al., 2011; Bizzarri et al., 2015). Considering the Bargiano site alone, in a stratigraphic section of about $5 \mathrm{~m}$ in thickness and across the 22 levels analyzed, a total of three WFEs were recognized. If the estimated sedimentation rate of $1 \mathrm{~m} / 10 \mathrm{ky}$ is correct, stratigraphic and sedimentological constraints imply that they probably occurred in an interval of about 50,000 years, with a frequency of about 18-20 k.y.

Regarding the presumed depth of these events, some information is provided by foraminifers. Orbulina universa, Globigerinoides ruber, and Globigerinoides sacculifer are all symbiont-bearing species, Globigerina bulloides and Turborotalita quinqueloba are surface dwellers and are consistently concentrated in the surface layer at an average depth of $<50 \mathrm{~m}$, and Globorotalia inflata is a surface-subsurface dweller at an average depth of between 50 m-100 m (Kucera, 2007; Rebotin et al., 2017).

These fluctuations in abundance appear related to sea-surface temperature and most likely, for symbiont-bearing taxa, to the depth of light penetration. Mud particles dispersed in seawater heavily influence light penetration and, for the BargianoAllerona area where clay and silt were regularly supplied by river-mouth discharge, the waters were surely less transparent and less able to be penetrated by light. This datum is aligned with what would be expected at intermediate depths, and our estimate of a depth of $100 \mathrm{~m}-150 \mathrm{~m}$ remains feasible. In accordance with these values, the Bargiano site-and the entire Allerona area more generally-represent a significant point of reference for the study of relatively shallow fossil WFEs.

In order to propose a comparison, available data on benthic foraminifera and crustacean associations from both fossil and present day WFEs are synthesized in Appendix 1. It is clear that data on benthic foraminifers are fewer (with regard to both fossil and present-day events) than those related to crustacean communities, which are often documented in present-day events. Furthermore, the fossil record of benthic foraminifera and decapod 
crustacean communities associated with WFEs is scarce and poorly reported (Appendix 1).

Concerning the benthic foraminifera associations reported from fossil WFEs (Appendix 1), few data exist. Amano and Little (2005) identified Martinottiella communis and Spirosigmoilinella compressa as biostratigraphic markers of the Miocene Chikubetsu $\mathrm{Fm}$. in which remains of a primitive mysticete were found, but they were not directly connected with the skeleton. Amano et al. (2007), working with undetermined cetacean remains from Miocene deposits in Japan, reported large $(\sim 300$ $\mu \mathrm{m}$ diameter) benthic biloculine miliolid foraminifera.

More data come from present-day WFEs. Wada et al. (1994) described how sediments rich in fatty acids, collected beneath a whale skeleton on the Torishima seamount (South of Japan), hosted a foraminifera assemblage characterized by Cassidulinoides parkerianus (dominant); 'Rhabdammina' (?=Saccorhiza) ramosa, Reophax scorpiurus, Recurvoides parkerae, Cystammina pauciloculata, Textularia kattegatensis, and Textularia sp. (all agglutinated species); Gyroidina quinqueloba, Tosaia hanzawai, Fursenkoina sp., Melonis pompilioides, and Epistominella exigua (all rotalids); and Spiroloculina sp. (a miliolid). The assemblage included both agglutinated and rotalid species, and epifaunal and infaunal genera (following the ecological description reported by Murray, 2006) seem to be represented equally. Unfortunately, data regarding the relative abundance of these specimens were not reported, and only C. parkeriana was characterized as dominant.

Rathburn (unpublished data in Gooday and Rathburn, 1999, p. 199) reported that "whale falls favor common species (e.g., Uvigerina peregrina and Globobulimina spp.), which are typically found in eutrophic conditions"; the authors also believed "it is possible that a succession of foraminiferal species may respond to the different phases of the carcass decomposition process."

Although the Bargiano foraminifera assemblages differ from those reported from present-day WFEs, some similarities can be identified. These largely involve families Textularidae and Eggerellidae and, more generally, the occurrence of agglutinated species. At Bargiano, detritivore epifaunal species (Lenticulina, Cancris, Cassidulina, Siphotextularia, Gyroidina, and Hyalinea) and shallow infaunal species (Bannerella, Fursenkoina, Bolivina, Nonionella, Melonis, Bulimina, Elphidium) dominate, while epifaunal herbivore and suspension feeders and the shallow infaunal omnivore species are subordinate. Compared to data from Wada et al. (1994) the Bargiano benthic foraminifera assemblage shows comparable organization, although environmental conditions $\quad(4,037 \mathrm{~m}$ in the Wada group's work) and sea bottom sediments are quite different. At Bargiano, moreover, the influx of organic matter was not linked to a single whale fall but was repeated and more-or-less continuous over time.

Contrary to decapods, distributed mainly at and around WFE 2, benthic foraminifers were influenced by all the Bargiano WFEs. First, the overall reduced number of taxa could indicate stressful environmental conditions, whereas the variability in $\mathrm{SD}$ demonstrates that the highest concentration of organic matter in sediments close to the whale skeleton became a limiting factor for the development of benthic taxa and for epifaunal taxa in particular. The shallow infaunal species Bigenerina nodosaria, Bannerella gibbosa, Marginulinopsis costata, and Vaginulina cf. V. striatissima; the epifaunal species Lenticulina calcar, and Siphotextularia concava dominated the poor assemblages, suggesting that nutrient enrichment was, conversely, favorable for them. As opportunistic species, they responded rapidly to short-term favorable circumstances by increasing their numbers; given their consistent presence in assemblages (across all 25 levels), it is possible to hypothesize that they were sedentary and carried out the life cycle through time, increasing in number and maintaining a stable population on the seabed in response to an increase in organic matter.

As reported by Smith et al. (2015), the dispersion of whale biomass leads to a "bull's eye" of elevated microbial enrichment and degradation activity in the sediment, which declines to background conditions beyond about $10 \mathrm{~m}$. Goffredi and Orphan (2010) also indicated that the sphere of influence of whale-fall-derived nutrients expanded laterally up to $20 \mathrm{~m}$ away, with changes in bacterial diversity. According to this evidence, our analyses of samples from the six short sections (Figures 1,2 ) located at varying distances from the whale carcass and close to fossil ambergris (cololites), highlight changes in benthic foraminifera assemblages and identify dominant taxa connected both to bacterial growth and to nutrient accumulation in the sediment. The increase of nutrients, relative to whale biomass dispersion and evidenced by frequencies of opportunistic benthic foraminifera, seems to confirm dispersion laterally around carcasses for at least $10 \mathrm{~m}$. We would add that the repeated overlap of WFE over time facili- 
tated the persistence of opportunistic taxa on the sea bottom, some of which assumed specialized forms, and favored their reproduction (as in the CFT section, for example).

The data reported here demonstrate that at least six benthic foraminifera taxa were endemic to fossil WFEs at Bargiano and that these taxa multiplied (through asexual multiple fission: Murray, 2006) in response to increased availability of food associated with a surge in organic matter. In the Mediterranean Sea, De Rijk et al. (1999, 2000) reported that the bathymetrical distribution of the main benthic foraminifera taxa was controlled by the flux of labile organic matter to the sea floor and that the upper and lower depth limits of several taxa corresponded closely to estimated flux isolines. In our case, the isolines corresponded to the WFEs (WFE 1-3).

The scarcity of data on foraminifera at shallow WFEs, however, contrasts with detailed research regarding benthic foraminifera communities in similar contexts, such as those associated with cold seeps (Levin, 2005, and references therein) at which the interactions of microfauna with flow, chemistry, and microbe development is more clearly shown.

As indicated by Levin (2005), the composition of foraminifera communities at seeps and their relationship to environmental factors have largely been analyzed in various geographic settings (the Gulf of Mexico, Central and Northern California, and off the coast of Japan). Differences noted in densities for reference genera and species indicate the biogeographic variation of communities, but most seep genera are also characteristic of other low-oxygen and organic-rich settings (Rathburn et al., 2000, 2003; Bernhard et al., 2001; Robinson et al., 2004). There is little information about seep effects on diversity, but studies have shown that diversity is reduced in seep sediments with respect to non-seep sediments (Robinson et al., 2004). Likewise, the vertical distribution of foraminifera varies with seepage, although the majority of seep species are considered infaunal. Infaunal foraminifera species tolerate low-oxygen and organic-rich conditions (Rathburn et al., 2000) and thrive at varying maximum depths according to habitat (bacterial mats vs. clam beds, for example), with subsurface peaks between $2 \mathrm{~cm}$ and $4 \mathrm{~cm}$. Species characteristic of shallow $(120 \mathrm{~m})$ methane seeps in the Santa Barbara Basin off California include Bolivina tumida, Epistominella pacifica, Oridorsalis umbonatus, and Uvigerina peregrina. Central and northern California seeps also support high densi- ties of Chilostomella, Globobulimina, Nonionella, Cassidulina, and Textularia (Bernhard et al., 2001; Rathburn et al., 2003).

It is noteworthy that five genera found by Bernhard et al. (2001) and Rathburn et al. (2003), Bolivina, Uvigerina, Nonionella, Cassidulina, and Textularia, are among those present as subsidiary taxa in Bargiano shallow whale-fall sediments; among these, Uvigerina, Siphotextularia (comparable to Textularia), and Bolivina, highlight an affinity for the kind of paleoenvironment found at Bargiano. The strong similarity between the two contexts (seeps and whale falls) is evident: both environments induce changes in associations (reducing diversity), and taxa are all infaunal opportunists, characteristics of oxygen-poor or organic-rich environments.

Regarding the decapods found at Bargiano, Albaidaplax ispalensis has previously been reported from the Pliocene and early Pleistocene of Andalusia (Spain) and Tuscany (Italy) (Garassino et al., 2013, p. 363). This finding represents the first record of Albaidaplax in the Umbria Region and the second in the early Pleistocene from Italy. Chlinocephalus demissifrons has been reported from three Pliocene localities in northern Italy: Fornaci (Savona, Liguria) (Ristori, 1886); Biella (Piedmont) (Garassino et al., 2004); and Castellarano (Emilia Romagna) (Pasini and Garassino, 2013). Garassino et al. (2004), moreover, pointed out that the specimen assigned by Ristori (1891) to Titanocarcinus sculptus Ristori, 1891, from the Pliocene of Mucigliani, Siena (Tuscany, central Italy) could be a juvenile stage of $C$. demissifrons. Based upon Italian reports known to date, the Bargiano specimens represent the first report of this species from Umbria, and the first in the early Pleistocene, extending the distribution and stratigraphic range of the species into the paleo-Mediterranean Basin. These data add to knowledge of decapod communities in or near fossil WFEs (Appendix 1).

The most complete list of brachyuran (Crustacea, Decapoda) crabs was provided by Fujiwara et al. (2007: figure 2b), who used high-definition TV video over three years to study and report on crustacean fauna associated with sperm-whale falls in the waters of Cape Nomamisaki (SE Japan) at depths of 219-250 m. They listed, among other crustaceans, the following brachyuran crabs, assigning them to families, as follows: Homola orientalis Henderson, 1888 (Homolidae); Ethusa sp. (Dorippidae); Cryptocnemus obolus Ortmann, 1893, and Merocryptus lambriformis A. MilneEdwards, 1873 (Leucosiidae); Macrocheira kaemp- 
feri (Temminck, 1836), Pugettia minor Ortmann, 1893, Oxypleurodon stimpsoni Miers, 1886 (Majidae); Trachycarcinus sagamiensis Rathbun, 1932 (Atelecyclidae); Cancer gibbosulus (De Haan, 1833-1849) and C. japonicus Ortmann, 1893 (Cancridae); Carcinoplax surugensis Rathbun, 1932 (Goneplacidae); "Medaeus serratus" Sakai, 1965 (Xanthidae); and Pinnixa sp. (Pinnotheridae); see Fujiwara et al. (2007: table 4).

Lundsten et al. (2010b: figure 5D) reported Chionoecetes tanneri Rathbun, 1893 (Oregoniidae) as feeding on a whale tissue (site reported as Whale-1018) from the deep floor of Monterey Canyon, California (USA). Based upon observations of extant brachyuran crabs, the report of Albaidaplax and Chlinocephalus (both Goneplacidae) could be strictly correlated with feeding behavior, as attested by the extant Carcinoplax. Regarding decapods from fossil WFEs, Lancaster (1986) and Nesbit (2005) reported the occurrence of Calappa sp. in Eocene sediments (associated with archaeocete bones), and of Callianopsis clallamensis (Withers, 1924 ) in late Oligocene deposits (with mysticete remains), respectively.

Only a few generic reports have considered fossil whale-fall localities in Italy. Danise and Dominici $(2014$, p. 236 , table 1$)$ noted that "decapods are also reported" among the fauna associated with the fossil bones of cetaceans from the Pliocene of Orciano Pisano and Ponte a Elsa (Tuscany), and Castellarano (Emilia Romagna), Italy. The decapods observed, but not collected, at Ponte a Elsa were associated with the skeleton of a large baleen whale and possibly referable to Goneplax. The specimens observed at Orciano Pisano, conversely, were closely associated with a cetacean skeleton and were referable to Eriphia (Brachyura, Eriphiidae). Unfortunately, due to their delicate nature, the specimens were broken during the field work that was mainly focused on recovery of the fossil skeleton (Dominici, personal commun., 2016).

As a consequence, the specimens from Bargiano stand out as the only confidently identified fossil brachyuran reported from a fossil whale-fall environment. The presence of several specimens nearby the carcass of the cetacean can be interpreted as opportunistic behavior by these decapod crustaceans due to the presence of a great, temporary availability of food on the sea bottom.

Unfortunately, the fossil evidence does not allow to determinate confidently the direct interaction between decapod crustaceans and the cetacean remains. Their presence around the bones might reveal a temporary assemblage of opportunistic scavenger crabs due to the presence of a copious source of food for a relatively long period. The Bargiano specimens, however, were collected only in proximity to whale bones and were apparently absent in the others layers of the outcrop, where only a few, poorly preserved decapods of other species have been collected (Garassino and Pasini, personal obs., 2016).

Unlike WFE2, the WFE1 and WFE3 lacked skeletal remains and Ambergrisichnus cololites are the only evidence of sperm-whale-carcass accumulation on the sea floor. In fact, rare, unidentifiable bone fragments were found all around these masses (Baldanza et al., 2013; Monaco et al., 2014). A large area around the study site was modified by human intervention about 30 years ago, when about $3 \mathrm{~m}$ of soil were removed to reveal the marine deposits, accelerating the formation of deep runoff furrows (Figure 1.2). Part of the bones may well have been lost, then, particularly if they were reduced to fragments. Such fragmentation probably had a biological origin; the destruction of lipid-rich sperm-whale bones, for example, could have been activated by boring worms such as the extant Osedax. As reported by Higgs et al. (2012), evidence of Osedax activity on fossil whale bones was documented in Pliocene deposits of Orciano Pisano, Tuscany. Therefore, the presence and activity of Osedax in the Allerona WFE area during the Pleistocene cannot be excluded.

Future research will include documenting the presence and activity of marine worms and, more generally, of chemosymbionts, on fossil bones, which at the moment are in the preliminary phase of restoration.

\section{CONCLUSIONS}

The paleontological heritage of the Bargiano site, where a cetacean skeleton and more than 27 fossil ambergris structures (linked to the presence of sperm-whale carcasses, Figure 1.2, 1.4-1.5) have been found, represents a window onto a shallow $(100 \mathrm{~m}-150 \mathrm{~m})$ early Pleistocene marine paleoenvironment that has proven ideal for an investigation of the relationships among opportunistic micro- and macrofauna in WFEs. The data regarding foraminifera communities and decapods recovered from Bargiano make clear that a locally high nutrient flux significantly influenced biota in the first few millimeters or centimeters of sea floor sediment. This increase in nutrients, related to whale-carcass biomass and evidenced by frequencies of opportunistic benthic foraminifera, appears 
to confirm lateral dispersion around the carcass for a radius of at least $10 \mathrm{~m}$.

The entire Allerona area represents an unusual paleoenvironment where several WFEs took place over a span of about 100,000 years (Monaco et al., 2014) with a probable increase in frequency of WFEs during the last 50 k.y. The data presented here allow us to recognize, in a 5-mthick stratigraphic section analyzed at a total of 25 levels, a total of three WFEs. If these events occurred as multiple cetacean death events, the shallow sea floor environment was enriched in organic matter, allowing opportunists (micro- and macrofauna, scavengers, and bacteria) to proliferate steadily.

\section{ACKNOWLEDGMENTS}

We wish to thank G. Teruzzi, Museo di Storia Naturale di Milano, for the photos of crab specimens; L. Bartolucci, Department of Physics and Geology (Perugia University), for SEM photos of foraminifers; and S. Dominici, Museo di Storia Naturale di Firenze, for useful discussion and suggestions concerning whale falls in Tuscany. We are also grateful to the students of the Department of Physics and Geology and the Department of Chemistry, Biology and Biotechnology (Perugia University) for their contributions to paleontological excavations (June-July 2016) and for their recovery of decapod specimens. Finally, we wish to thank J. Luque, N. Higgs, and M. Hyžný for their suggestions for improving the manuscript, and W. Ricketts for the accurate revision of the English text.

\section{REFERENCES}

Amano, K. and Little, C.T.S. 2005. Miocene whale-fall community from Hokkaido, northern Japan. Palaeogeography, Palaeoclimatology, Palaeoecology, 215:345-356. https://doi.org/ 10.1016/j.palaeo.2004.10.003

Amano, K., Little, C.T.S., and Inoue, K. 2007. A new Miocene whale-fall community from Japan. Palaeogeography, Palaeoclimatology, Palaeoecology, 247:236-242. https://doi.org/10.1016/ j.palaeo.2006.10.017

Amon, D.J., Glover, A.G., Wiklund, H., Marsh, L., Linse, K., Rogers, A.D., and Copley, J.T. 2013. The discovery of a natural whale fall in the Antarctic deep sea. Deep-Sea Research II, 92:8796. https://doi.org/10.1016/j.dsr2.2013.01.028

Backman, J., Raffi, I., Rio, D., Fornaciari, E., and Pälike, H. 2012. Biozonation and biochronology of Miocene through Pleistocene calcareous nannofossils from low and middle latitudes. Newsletters on Stratigraphy, 45:221-244. https://doi.org/10.1127/0078-0421/2012/0022

Baldanza, A., Bizzarri, R., Famiani, F., Monaco, P., Pellegrino, R., and Sassi, P. 2013. Enigmatic, biogenically induced structures in Pleistocene marine deposits: a first record of fossil ambergris. Geology, 41:1075-1078. https://doi.org/10.1130/g34731.1

Baldanza, A., Bizzarri, R., Famiani, F., Pasini, G., Garassino, A., and De Angeli, A. 2014. Early Pleistocene shallow marine decapod crustaceans community from Fabro Scalo (western Umbria, central Italy): taxonomic inferences and palaeoenvironmental reconstruction. Neues Jahrbuch für Geologie und Paläontologie, 271:261-283. https://doi.org/10.1127/0077-7749/ 2014/0389

Baldanza, A., Bizzarri, R., and Hepach, H. 2011. New biostratigraphic data from the early Pleistocene Tyrrhenian paleocoast (western Umbria, central Italy). Geologia Croatica, 64:133-142. https://doi.org/10.4154/gc.2011.11

Bennett, B.A., Smith, C.R., Glaser B., and Maybaum, H.L. 1994. Faunal community structure of a chemoautotrophic assemblage on whale bones in the deep northeast Pacific Ocean. Marine Ecology Progress Series, 108:205-223. https://doi.org/10.3354/meps108205

Bernhard, J.M., Buck, K.R., and Barry, J.P. 2001. Monterey Bay cold-seep biota: assemblages, abundance, and ultrastructure of living foraminifera. Deep Sea Research, Part I, 48:22332249. https://doi.org/10.1016/s0967-0637(01)00017-6

Bianucci, G. 2014. Fossil cetaceans in Italian museums. Museologia Scientifica Memorie, 13:717.

Bizzarri, R., Rosso, A., Famiani, F., and Baldanza, A. 2015. Lunulite bryozoans from Early Pleistocene deposits of SW Umbria (Italy): sedimentological and paleoecological inferences. Facies, 61:420. https://doi.org/10.1007/s10347-014-0420-6 
Castro, P. and Ng, P.K.L. 2010. Revision of the family Euryplacidae Stimpson 1871 (Crustacea: Decapoda: Brachyura: Goneplacoidea). Zootaxa, 2375:1-130.

Chendes, C., Kaminski, M.A., Filipescu, S., Aksu, A.E., and Yasar, D. 2004. The response of modern benthic foraminiferal assemblages to water-mass properties along the southern shelf of Marmara Sea. Acta Palaeontologica Romaniae, 4:69-80.

Dahlgren, T.G., Wiklund, H., Källström, B., Lundälv, T., Smith, C.R., and Glover, A.G. 2006. A shallow-water whale-fall experiment in the north Atlantic. Cahiers de Biologie Marine, 47:385-389.

Danise, S. and Dominici, S. 2014. A record of fossil shallow-water whale falls from Italy. Lethaia, 47:229-243. https://doi.org/10.1111/let.12054

Danise, S., Dominici, S., and Betocchi, U. 2010. Mollusk species at a Pliocene shelf whale fall (Orciano Pisano, Tuscany). Palaios, 25:449-456. https://doi.org/10.2110/palo.2009.p09-139r

Danise, S., Dominici, S., Glover, A.G., and Dahlgren, T.G. 2014. Molluscs from a shallow-water whale-fall and their affinities with adjacent benthic communities on the Swedish west coast. Marine Biology Research, 10:3-16. https://doi.org/10.1080/17451000.2013.793811

De Haan, H.M. 1833-1849. Crustacea. In Siebold, P.F.V. (ed.), Fauna Japonica, sive Descriptio animalium, quae in itinere per Japoniam, jussu et auspiciis superiorum, qui summum in India Batavia imperium tenent, suscepto, annis 1823-1830 collegit, notis, observationibus a adumbrationibus illustravit. Lugduni Batavorum, J. Müller et Co.

De Rijk, S., Jorissen, F.J., Rohling, E.J., and Troelstra, S.R. 2000. Organic flux control on bathymetric zonation of Mediterranean benthic foraminifera. Marine Micropaleontology, 40:151-166. https://doi.org/10.1016/s0377-8398(00)00037-2

De Rijk, S., Troelstra, S.R., and Rohling, E.J. 1999. Benthic foraminiferal distribution in the Mediterranean Sea. Journal of Foraminifera Research, 29:93-103. https://doi.org/10.2113/ gsjfr.29.2.93

de Stigter, H.C., Jorissen, F.J., and Zwann van der, G.J.1998. Bathymetric distribution and microhabitat partitioning of live (rose Bengal stained) benthic foraminifera along a shelf to bathyal transect in the Southern Adriatic Sea. Journal of Foraminiferal Research, 28:40-65.

Dominici, S., Cioppi, E., Danise, S., Betocchi, U., Gallai, G., Tangocci, F., Valleri, G., and Monechi, S. 2009. Mediterranean fossil whale falls and the adaptation of mollusks to extreme habitats. Geology, 37:815-818. https://doi.org/10.1130/g30073a.1

Ellis, B.F. and Messina, A. 1940-2006. Catalogue of Foraminifera. Micropaleontology Press, American Museum of Natural History, New York.

Fontanier, C., Jorissen, F.J., Licari, L., Alexandre, A., Anschutz, P., and Carbonel, P. 2002. Live benthic foraminiferal faunas from the Bay of Biscay: Faunal density, composition, and microhabitats. Deep Sea Research, Part I, 49:751-785. https://doi.org/10.1016/s09670637(01)00078-4

Fujioka, K., Wada, H., and Okano, H. 1993. Torishima whale bone deep-sea animal community assemblage - new finding by Shinkai 6500. Journal of Geography, 102:507-517 (in Japanese with English abstract). https://doi.org/10.5026/jgeography.102.507

Fujiwara, Y., Kawato, M., Yamamoto, T., Yamanaka, T., Sato-Okoshi, W., Noda, C., Tsuchida, S., Komai, T., Cubelio, S.S., Sasaki, T., Jacobsen, K., Kubokawa, K., Fujikura, K., Maruyama, T., Furushima, Y., Okoshi, K., Miyake, H., Miyazaki, M., Nogi, Y., Yatabe, A., and Okutani, T. 2007. Three-year investigations into sperm whale-fall ecosystems in Japan. Marine Ecology, 28:219-232. https://doi.org/10.1111/j.1439-0485.2007.00150.x

Garassino, A., De Angeli, A., Gallo, M.L., and Pasini, G. 2004. Brachyuran and anomuran fauna from the Cenozoic of Piedmont (NW Italy). Atti della Società italiana di Scienze naturali e del Museo civico di Storia naturale in Milano, 145:251-281.

Garassino, A., Pasini, G., and Castro, P. 2013. Revision of the fossil species of Goneplax Leach, 1814 (Crustacea, Decapoda, Brachyura, Goneplacidae). Boletín de la Sociedad Geológica Mexicana, 65:355-368.

Geist, J. 2010. October/November. Sound Waves, 128:6-8. Whale falls. Available from https:// soundwaves.usgs.gov/2010/11/SW201011-100.pdf.

Goffredi, S.K. and Orphan, V.J. 2010. Bacterial community shifts in taxa and diversity in response to localized organic loading in the deep sea. Environmental Microbiology, 12:344363. https://doi.org/10.1111/j.1462-2920.2009.02072.x

Goffredi, S.K., Paull, C.K., Fulton-Bennett, K., Hurtado, L.A., and Vrijenhoek, R.C. 2004. Unusual benthic fauna associated with a whale fall in Monterey Canyon, California. Deep-Sea Research I, 51:1295-1306. https://doi.org/10.1016/j.dsr.2004.05.009 
Goffredi, S.K., Wilpiszeski, R., Lee, R., and Orphan, V. 2008. Temporal evolution of methane cyling and phylogenetic diversity of archaea in sediments from a deep-sea whale-fall in Monterey Canyon, California. The ISME Journal, 2:204-220. https://doi.org/10.1038/ ismej.2007.103

Gooday, A.J. and Rathburn, A.E. 1999. Temporal variability in living deep-sea benthic foraminifera: a review. Earth-Science Reviews, 46:187-212. https://doi.org/10.1016/s00128252(99)00010-0

Gross, O. 2000. Influence of temperature, oxygen and food availability on the migrational activity of bathyal benthic foraminifera: evidence by microcosm experiments. Hydrobiologia, 426:123-137. https://doi.org/10.1007/978-94-011-4148-2_12

Henderson, J.R. 1888. Report on the Anomura collected by H.M.S. Challenger during the years 1873-76. Report on the Scientific Results of the Voyage of H.M.S. Challenger during the years 1873-76. Zoology, 27:1-221.

Higgs, N.D., Glover, A.G., Dahlgren, T.G., and Little, C.T.S. 2010. Using computed tomography to document borings by Osedax mucofloris in whale bone. Cahiers de Biologie Marine, 51:401405.

Higgs, N.D., Little, C.T.S., Glover, A.G., Dahlgren, T.G., Smith, C.R., and Dominici, S. 2012. Evidence of Osedax worm borings in Pliocene ( $3 \mathrm{Ma})$ whale bone from the Mediterranean. Historical Biology, 24:269-77. https://doi.org/10.1080/08912963.2011.621167

laccarino, S. and Premoli Silva, I. 2007. Practical Manual of Neogene Planktonic Foraminifera. International School on Planktonic Foraminifera, VI Course: Neogene, Perugia.

Jorissen, F.J., Barmawidjaja, D.M., Puskaric, S., and Zwaan van der, G.J. 1992. Vertical distribution of benthic Foraminifera in the northern Adriatic Sea: the relation with high organic flux. Marine Micropaleontology, 19:131-146. https://doi.org/10.1016/0377-8398(92)90025-f

Kaminski, M.A., Aksu, A., Box, M., Hiscott, R.N., Filipescu, S., and Al-Salameen, M. 2002. Late Glacial to Holocene benthic foraminifera in the Marmara Sea: implications for Black Sea Mediterranean Sea connections following the last deglaciation. Marine Geology, 190:162202. https://doi.org/10.1016/s0025-3227(02)00347-x

Karasawa, H. and Kato, H. 2003. The family Goneplacidae MacLeay, 1838 (Crustacea: Decapoda: Brachyura): systematics, phylogeny, and fossil records. Paleontological Research, 7:129-151. https://doi.org/10.2517/prpsj.7.129

Kemp, K.M., Jamieson, A.J., Bagley, P.M., McGrath, H., Bailey, D.M., Collins, M.A., and Priede, I.G. 2006. Consumption of large bathyal food fall, a six month study in the NE Atlantic. Marine Ecology Progress Series, 310:65-76. https://doi.org/10.3354/meps310065

Kucera, M. 2007. Chapter six: Planktonic foraminifera as tracers of past oceanic environments, p. 213-262. In Hillaire-Marcel, C. and de Vernal, A. (eds.), Proxies in Late Cenozoic Paleoceanography, Developments in Marine Geology. Elsevier. https://doi.org/10.1016/ s1572-5480(07)01011-1

Lancaster, W.C. 1986. The taphonomy of an archaeocete skeleton and its associated fauna, $p$. 119-131. In Schiebout, J.A. and van den Bold, W. (eds.), Montgomery Landing Site, Marine Eocene (Jackson) of Central Louisiana. Gulf Coast Association of Geological Societies.

Levin, L.A. 2005. Ecology of cold seep sediments: interactions of fauna with flow, chemistry and microbes. Oceanography and Marine Biology: An Annual review, 43:1-46. https://doi.org/ 10.1201/9781420037449.ch1

Linse, K., Jackson, J.A., Malyutina, M.V., and Brandt, A. 2014. Shallow-water northern hemisphere Jaera (Crustacea, Isopoda, Janiridae) found on whale bones in the Southern Ocean deep sea: ecology and description of Jaera tyleri sp. nov. PLoS ONE, 9: e93018. https://doi.org/10.1371/journal.pone.0093018

Lundsten, L., Paull, C.K., Kyra L. Schlining, K.L., McGann, M., and Ussler, W. III 2010a. Biological characterization of a whale-fall near Vancouver Island, British Columbia, Canada. Deep-Sea Research I, 57:918-922. https://doi.org/10.1016/j.dsr.2010.04.006

Lundsten, L., Schlining, K.L., Frasier, K., Johnson, S.B., Kuhnz, L.A., Harvey, J.B.J., Clague, G., and Vrijenhoek, R.C. 2010b. Time-series analysis of six whale-fall communities in Monterey Canyon, California, USA. Deep-Sea Research I, 57:1573-1584. https://doi.org/10.1016/ j.dsr.2010.09.003

MacLeay, W.S. 1838. Illustrations of the Annulosa of South Africa; being a portion of objects of natural history chiefly collected during an expedition into the interior of South Africa, under the direction of Dr. Andrew Smith, in the years 1834, 1835, and 1836; fitted out by "The Cape 
of Good Hope Association for exploring Central Africa": Illustrations of the zoology of South Africa (Invertebrate). Smith, Elder, and Co., London.

Mayoral, E., Müller, P., and Muñiz, F. 1998. Lower Pliocene decapod crustaceans from the southwestern Iberian Peninsula (Guadalquivir Basin, Sevilla, Spain). Geobios, 31:505-510. https://doi.org/10.1016/s0016-6995(98)80122-8

Milne-Edwards, A. 1873. Groupe des cyclometopes. Portuniens. Recherches sur la faune carcinologique de la Nouvelle Calédonie, deuxième partie. Nouvelles Archives du Muséum d'Histoire naturelle de Paris, 9:155-352.

Monaco, P., Baldanza, A., Bizzarri, R., Famiani, F., Lezzerini, M., and Sciuto, F. 2014. Ambergris cololites of Pleistocene sperm whales from central Italy and description of the new ichnogenus and ichnospecies Ambergrisichnus alleronae. Palaeontologia Electronica 17.2.29A:20p, palaeo-electronica.org/content/2014/824-ambergrisichnus-alleronae

Mojtahid, M., Griveaud, C., Fontanier, C., Anschutz, P., and Jorissen, F.J. 2010. Live benthic foraminiferal faunas along a bathymetrical transect $(140-4800 \mathrm{~m})$ in the Bay of Biscay (NE Atlantic). Revue de Micropaleontology, 53:139-162. https://doi.org/10.1016/ j.revmic.2010.01.002

Murray, J. 1991. Ecology and palaeoecology of benthic foraminifera. Longman, London. https:// doi.org/10.4324/9781315846101

Murray, J. 2006. Ecology and Applications of Benthic Foraminifera. Cambridge University Press, Cambridge. https://doi.org/10.1017/cbo9780511535529

Naganuma. T., Wada, H., and Fujioka, K. 1996. Biological community and sediment fatty acids associated with the deep-sea whale skeleton at the Torishima seamount. Journal of Oceanography, 52:1-15. https://doi.org/10.1007/bf02236529

Nesbitt, E.A. 2005. A novel trophic relationship between cassid gastropods and mysticete whale carcasses. Lethaia, 38:17-25. https://doi.org/10.1080/00241160510013132

Ortmann, A.E. 1893. Die Decapoden-Krebse des Strassburger Museums, mit besonderer Berücksichtigung der von Herrn Dr. Döderlein bei Japan und bei den Liu-Kiu Inseln gesammelten und zur Zeit im Strassburger Museum aufbewahrten Formen. VI Theil. Abtheilung: Brachyura (Brachyura genuine Boas). I. Unterabtheilung: Majoidea und Cancroidea, 1: Section Portuninea. Zoologische Jahrbücher, Abteilung für Systematik, Geographie und Biologie der Thiere, 7(1):23-88.

Pasini, G. and Garassino, A. 2013. Records of brachyuran crabs from the Pliocene (Piacenzian) of Reggio Emilia (Emilia Romagna, N Italy). Buletín de la Sociedad Geológica Mexicana, 65:319-328.

Pasini, G., Garassino, A., and De Angeli, A. 2017. Asthenognathus alleronensis n. sp. (Decapoda, Brachyura, Varunidae) from the early Pleistocene of Bargiano, Terni (Umbria, central Italy). Neues Jahrbuch für Geologie und Paläontologie, 283:69-71. https://doi.org/ 10.1127/njgpa/2017/0627

Pavlyuk, O.N., Trebukhova, Y.A., and Tarasov, V.G. 2009. The impact of implanted whale carcass on nematode communities in shallow water area of Peter the Great Bay (East Sea). Ocean Science Journal, 44:181-188. https://doi.org/10.1007/s12601-009-0016-1

Rathbun, M.J. 1893. Descriptions of new genera and species of crabs from the west coast of North America and the Sandwich Islands. Proceedings of the United States National Museum, 16(933):223-260.

Rathbun, M.J. 1932. Preliminary descriptions of new species of Japanese crabs. Proceedings of the Biological Society of Washington, 45:28-38.

Rathburn, A.E., Levin, L. A., Held, Z.A., and Lohmann, K.C. 2000. Benthic foraminifera associated with cold methane seeps on the Northern Californian margin: ecology and stable isotopic composition. Marine Micropaleontology, 38:247-266. https://doi.org/10.1016/s03778398(00)00005-0

Rathburn, A.E., Pérez, M.E., Martin, J.B., Day, S.A., Mahn, C., Gieskes, J., Ziebis, W., Williams, D., and Bahls, A. 2003. Relationships between the distribution and stable isotopic composition of living benthic foraminifera and cold methane seep biogeochemistry in Monterey Bay, California. Geochemistry Geophysics Geosystems, 4(12):1106. https:// doi.org/10.1029/2003gc000595

Rebotin, A., Voelker, A. H. L., Jonkers, L., Waniek, J. J., Meggers, H., Schiebel,F., Fraile, I., Schulz, M., and Kucera, M. 2017. Factors controlling the depth habitat of planktonic foraminifera in the subtropical eastern North Atlantic. Biogeosciences, 14:827-859. https:// doi.org/10.5194/bg-14-827-2017 
Ristori, G. 1886. I Crostacei brachiuri e anomuri del Pliocene Italiano. Bollettino della Società Geologica Italiana, 5:93-130.

Ristori, G. 1891. Contributo alla fauna Carcinologica del Pliocene Italiano. Atti della Società Toscana di Scienze Naturali, memorie, 11:3-18.

Robinson, C.A., Bernhard, J.M., Levin, L.A., and Mendoza, G.F. 2004. Meiofauna and macrofauna of near-surface hydrocarbon seep habitats: Blake Ridge Diapir (Atlantic Ocean) and Alaminos Canyon (Gulf of Mexico). Pubblicazioni della Stazione Zoologica di Napoli. I. Marine Ecology, 25:313-336.

Roman, J., Estes, J.A., Morissette, L., Smith, C.R. Costa, D., McCarthy, J., Nation J.B., Nicol, S., Pershing, A., and Smetacek, V. 2014. Whales as marine ecosystem engineers. Frontiers in Ecology and the Environment, 12:377-385. https://doi.org/10.1890/130220

Rosatini, F. 2016. Benthic foraminifera, mollusc and ostracod assemblages close to evisceralites and cetacean carcasses in the Bargiano site (Allerona, Terni): palaeoenvironmental and palaeoecological reconstruction. Unpublished MS Thesis, University of Perugia, Perugia, Italy.

Schrodt, F. 1890. Beitrage zur Kenntniss der Pliocanfauna Sud-Spaniens. Deutsche Geologische Gesellschaft Zeitschriften, Berlin, Deutschland. Bd.42, p. 412.

Schweitzer, C.E., Feldmann, R.M., Garassino, A., Karasawa, H., and Schweigert, G. 2010. Systematic list of fossil decapod crustacean species. Crustaceana Monographs, 10:1-222. https://doi.org/10.1163/193724012x626575

Sgarella, F. and Moncharmont-Zei, M. 1993. Benthic foraminifera of the Gulf of Naples (Italy): systematic and autoecology. Bollettino della Società Paleontologica Italiana, 32:145-264.

Smith, C.R. 2006. Bigger is better: The roles of whales as detritus in marine ecosystems, p. 286301. In Estes, J.A., DeMaster, D.P., Brownell Jr., R.L., Doak, D.F., and Williams, T.M. (eds.), Whales, Whaling and Ocean Ecosystems. University of California Press, Berkeley, CA, USA. https://doi.org/10.1525/california/9780520248847.003.0022

Smith, C.R and Baco, A.R. 2003. Ecology of whale falls at the deep-sea floor. Oceanography and Marine Biology: An Annual Review, 41:311-354.

Smith, C.R., Baco, A.R., and Glover, A.G. 2002. Faunal succession on replicate deep-sea whalefalls: Time scales and vent-seep affinities. Cahiers de Marine Biologie, 43:293-297.

Smith, C.R., Glover, A.G., Treude, T., Higgs, N.D., and Amon, D.J. 2015. Whale-fall ecosystems: recent insights into ecology, paleoecology, and evolution. Annual review of Marine Science, 7:571-596. https://doi.org/10.1146/annurev-marine-010213-135144

Smith, K.E., Thatje, S., Singh, H., Amsler, M.O., Vos, S.C., McClintock, J.B., Brothers, C.J., Brown, A., Ellis, D., Anderson, J.S., and Aronson, R.B. 2014. Discovery of a recent, natural whale fall on the continental slope off Anvers Island, western Antarctic Peninsula. Deep-Sea Research I, 90:76-80. https://doi.org/10.1016/j.dsr.2014.04.013

Solé, J. and Vía, L. 1989. Crustacis Decàpodes fòssils dels Països Catalano. Batalleria, 2:23-42.

Stimpson, W. 1871. Preliminary Report on the Crustacea dredged in the Gulf Stream in the Straits of Florida, by L.F. de Pourtales, Assist. U.S. Coast Survey. Part I. Brachyura. Bulletin of the Museum of Comparative Zoology at Harvard College, in Cambridge, 2:109-160.

Sumida, P.Y.G., Alfaro-Lucas, J.M., Shimabukuro, M., Kitazato, H., Perez, J.A.A., SoaresGomes, A., Toyofuku, T., Lima, A.O.S., Ara, K., and Fujiwara, Y. 2016. Deep-sea whale fall fauna from the Atlantic resembles that of the Pacific Ocean. Scientific Reports, 6:22139, https://doi.org/10.1038/srep22139

Taboada, S., Bas, M., Leiva, C., Garriga, M., Sard, R., and Avila, C. 2016. Life after death: shallow-water Mediterranean invertebrate communities associated with mammal bones. Marine Ecology, 37(1):164-178. https://doi.org/10.1111/maec.12257

Vía, L. 1948. Braquiuros fósiles de Barcelona y sus alrededores. Anales de la Escuela de Peritos Agricolas y de Servicios Técnicos de Agricultura, 7:143-152.

Wada, H. 1993. Torishima whale-bone animal community (TOWBAC). Shizuoka Chigaku (Shizuoka Geology), 67:1-3 (in Japanese). https://doi.org/10.5026/jgeography.102.507

Wada, H., Naganuma, T., Fujioka, K., Kitazato, H., Kawamura, K., and Akazawa, Y. 1994. The discovery of the Torishima whale bone animal community and its meaning. Journal of DeepSea Research, 10:37-47.

Withers, T.H. 1924. Some decapod crustaceans (Callianassa and Ranina) from the Oligocene of Washington State, USA. Annals and Magazine of Natural History, series 9, 14:121-127. 


\section{APPENDIX 1.}

Occurrence of benthic foraminifers, decapods, and other crustaceans on whale-falls, as reported in literature.

\begin{tabular}{|c|c|c|c|c|c|c|c|}
\hline \multirow{2}{*}{ Age } & \multirow{2}{*}{ Region } & \multirow{2}{*}{$\begin{array}{c}\text { Depth/ } \\
\text { Environmen } \\
t\end{array}$} & \multirow{2}{*}{$\begin{array}{l}\text { Cetacean } \\
\text { Taxon }\end{array}$} & \multicolumn{2}{|c|}{ Crustaceans } & \multirow{2}{*}{ Benthic foraminifers } & \multirow{2}{*}{ References } \\
\hline & & & & Other & Decapods & & \\
\hline Eocene & USA (LA) & Shelf & Archaeocete & $\begin{array}{l}\text { Arcoscalpellum } \\
\text { jacksonensis }\end{array}$ & Calappa sp. & & Lancaster, 1986 \\
\hline $\begin{array}{l}\text { late } \\
\text { Oligocene }\end{array}$ & USA (WA) & Bathyal & Mysticete & & $\begin{array}{l}\text { Callianopsis } \\
\text { clallamensis }\end{array}$ & & Nesbit, 2005 \\
\hline Miocene & $\begin{array}{l}\text { Japan } \\
\text { (northwestern } \\
\text { Hokkaido) }\end{array}$ & Bathyal & $\begin{array}{l}\text { primitive } \\
\text { Mysticete }\end{array}$ & & & $\begin{array}{l}\text { Martinotiella communis, } \\
\text { Spirosigmoilinella } \\
\text { compressa }\end{array}$ & $\begin{array}{l}\text { Amano and } \\
\text { Little, } 2005\end{array}$ \\
\hline Miocene & $\begin{array}{l}\text { Japan (eastern } \\
\text { Hokkaido) }\end{array}$ & $\begin{array}{l}\text { Upper } \\
\text { bathyal } \\
(200-500 \mathrm{~m}) \\
\text { to Lower } \\
\text { sublittoral } \\
(50-200 \mathrm{~m})\end{array}$ & Indeterminate & & & $\begin{array}{l}\text { large ( } ? 300 \mu \text { m diameter) } \\
\text { benthic biloculine miliolid } \\
\text { foraminifera, benthic } \\
\text { foraminifera }\end{array}$ & $\begin{array}{l}\text { Amano et al., } \\
2007\end{array}$ \\
\hline Pliocene & $\begin{array}{l}\text { Italy - Ponte a } \\
\text { Elsa (Pisa) }\end{array}$ & Shelf & Mysticete & & $\begin{array}{l}\text { Decapods (?Goneplax } \\
\text { sp.) }\end{array}$ & & $\begin{array}{l}\text { Danise and } \\
\text { Dominici, } 2014\end{array}$ \\
\hline Pliocene & $\begin{array}{l}\text { Italy - Orciano } \\
\text { Pisano (Pisa) }\end{array}$ & Shelf & Mysticete & & Decapods (Eriphia sp.) & & $\begin{array}{l}\text { Danise and } \\
\text { Dominici, 2014, } \\
\text { Dominici, pers. } \\
\text { comm. } 2016\end{array}$ \\
\hline $\begin{array}{l}\text { early } \\
\text { Pleistocene }\end{array}$ & $\begin{array}{l}\text { Italy - Bargiano } \\
\text { (Terni) - WFE2 }\end{array}$ & $100-150 \mathrm{~m}$ & Mysticete & & $\begin{array}{l}\text { Albaidaplax ispalensis, } \\
\text { Chlinocephalus } \\
\text { demissifrons, } \\
\text { Asthenognatus } \\
\text { alleronensis*, }^{*} \\
\text { ?Goneplax sp*., Jaxea } \\
\text { sp. }^{*},(?) \text { thalassinidean } \\
\text { and (?)goneplacid } \\
\text { burrows }\end{array}$ & $\begin{array}{l}\text { Dominant: Bannerella } \\
\text { gibbosa, Bigenerina } \\
\text { nodosaria, Lenticulina } \\
\text { calcar, Marginulinopsis } \\
\text { costata, Siphotextularia } \\
\text { concava, Vaginulina } \\
\text { striatissima (see Appendix } \\
2 \text { for the complete list) }\end{array}$ & $\begin{array}{l}\text { this work; } \\
\text { *Pasini et al., } \\
2017\end{array}$ \\
\hline Present day & $\begin{array}{l}\text { NW Pacific } \\
\text { (Torishima } \\
\text { Seamount) }\end{array}$ & $4037 \mathrm{~m}$ & Mysticete & & Munidopsis spp. & $\begin{array}{l}\text { Cassidulinoides } \\
\text { parkerianus (dominant), } \\
\text { 'Rhabdammina' } \\
\text { (?=Saccorhiza) ramosa, } \\
\text { Reophax scorpiurus, } \\
\text { Recuroides parkerae, } \\
\text { Cystammina } \\
\text { pauciloculata, Textularia } \\
\text { kattegatensis, Textularia } \\
\text { sp., Gyroidina } \\
\text { quinqueloba, Tosaia } \\
\text { hanzawai, Fursenkoina } \\
\text { sp., Melonis pompilioides, } \\
\text { Epistominella exigua, } \\
\text { Spiroloculina sp. }\end{array}$ & $\begin{array}{l}\text { Fujioka et al., } \\
\text { 1993;Wada, } \\
\text { 1993; Wada et } \\
\text { al., 1994; } \\
\text { Naganuma et } \\
\text { al., 1996 }\end{array}$ \\
\hline Present day & $\begin{array}{l}\text { NE Pacific (off } \\
\text { southern } \\
\text { California, Santa } \\
\text { Catalina Basin, } \\
\text { San Clemente } \\
\text { Basin, San } \\
\text { Nicolas, San } \\
\text { Diego Trough, } \\
\text { Santa Cruz } \\
\text { Basin) }\end{array}$ & $960-1960$ m & Mysticete & $\begin{array}{l}\text { Small lysianassid } \\
\text { amphipods, } \\
\text { Illyarachna } \\
\text { profunda }\end{array}$ & $\begin{array}{l}\text { Lithodid crabs } \\
\text { (Paralomis } \\
\text { multispina?), } \\
\text { Galatheids } \\
\text { (Munidopsis } \\
\text { quadrata*), } \\
\text { Indeterminate } \\
\text { crustaceans }\end{array}$ & & $\begin{array}{l}\text { *Bennet et al., } \\
\text { 1994, Smith and } \\
\text { Baco, } 2003\end{array}$ \\
\hline
\end{tabular}


BALDANZA ET AL.: WHALE-FALL PALEO-COMMUNITY

\begin{tabular}{|c|c|c|c|c|c|c|c|}
\hline \multirow{2}{*}{ Age } & \multirow{2}{*}{ Region } & \multirow{2}{*}{$\begin{array}{c}\text { Depth/ } \\
\text { Environmen } \\
t\end{array}$} & \multirow{2}{*}{$\begin{array}{l}\text { Cetacean } \\
\text { Taxon }\end{array}$} & \multicolumn{2}{|c|}{ Crustaceans } & \multirow{2}{*}{ Benthic foraminifers } & \multirow{2}{*}{ References } \\
\hline & & & & Other & Decapods & & \\
\hline Present day & & & & & & $\begin{array}{l}\text { Uvigerina peregrina, } \\
\text { Globobulimina spp. }\end{array}$ & $\begin{array}{l}\text { Rathburn in } \\
\text { Gooday and } \\
\text { Rathburn, 1999 }\end{array}$ \\
\hline Present day & $\begin{array}{l}\text { Oceanic North } \\
\text { Atlantic, South } \\
\text { Atlantic, western } \\
\text { Pacific, South } \\
\text { Pacific (several } \\
\text { sites) }\end{array}$ & unknown & unknown & & Galatheidae indet. & & $\begin{array}{l}\text { Smith and } \\
\text { Baco, } 2003\end{array}$ \\
\hline Present day & $\begin{array}{l}\text { NE Pacific } \\
\text { (Monterey } \\
\text { Canyon) }\end{array}$ & $382-289 \mathrm{~m}$ & Mysticete & Amphipods & $\begin{array}{l}\text { Indeterminate } \\
\text { decapods, } \\
\text { Chionoecetes tanneri, } \\
\text { Munidopsis bracteosa, } \\
\text { M. albatrossae, M. } \\
\text { cascadia, } \\
\text { Colossendeis gigas, C. } \\
\text { japonica, Paralomis } \\
\text { multispina, Paralomis } \\
\text { verrilli, Galatheidae } \\
\text { indet. }\end{array}$ & Epistominella pacifica* & $\begin{array}{l}\text { Goffredi et al., } \\
\text { 2004; Lundsten } \\
\text { et al., 2010b; } \\
\text { *Geist, } 2010\end{array}$ \\
\hline Present day & $\begin{array}{l}\text { North Sea } \\
\text { (Kosterfjord, } \\
\text { Sweden) }\end{array}$ & $30-125 \mathrm{~m}$ & Mysticete & $\begin{array}{l}\text { Orchomene } \\
\text { obtusa, } \\
\text { Ostracods* }\end{array}$ & Hyas araneus* & Benthic foraminifers* & $\begin{array}{l}\text { Dahlgren et al., } \\
2006 \text {; } \\
\text { *Danise et al., } \\
2014\end{array}$ \\
\hline Present day & $\begin{array}{l}\text { NE Atlantic } \\
\text { (Porcupine } \\
\text { Seahight) }\end{array}$ & $\begin{array}{l}2555-2710 \\
m\end{array}$ & $\begin{array}{l}\text { Odontocete } \\
\text { (Phocoena } \\
\text { phocoena) }\end{array}$ & $\begin{array}{l}\text { Eurythenes } \\
\text { gryllus, Tmetonyx } \\
\text { sp., } \\
\text { Abyssorchomene } \\
\text { sp. }\end{array}$ & Munidopsis crassa & & $\begin{array}{l}\text { Kemp et al., } \\
2006\end{array}$ \\
\hline Present day & $\begin{array}{l}\text { Off southern } \\
\text { Japan (Kyushu } \\
\text { Island) }\end{array}$ & $219-254 \mathrm{~m}$ & $\begin{array}{l}\text { Odontocete } \\
\text { (sperm } \\
\text { whales) }\end{array}$ & $\begin{array}{l}\text { Ostracoda, } \\
\text { Heteralepas sp., } \\
\text { Nebaliidae indet., } \\
\text { Gammaridae } \\
\text { indet., Cumacea } \\
\text { indet., } \\
\text { Euphausiacea } \\
\text { indet., }\end{array}$ & $\begin{array}{l}\text { Alpheus sp. } \\
\text { (macrochirus group?), } \\
\text { Eualus sp. cf. kikuchii, } \\
\text { Processa } \\
\text { philippinensis, } \\
\text { Plesionika crosnieri, } \\
\text { Plesionika grandis, } \\
\text { Callianassa s.l. sp., } \\
\text { Cestopagurus sp. nov., } \\
\text { Paguristes } \\
\text { albimaculatus, } \\
\text { Nematopagurus } \\
\text { lepidochirus, } \\
\text { Nematopagurus } \\
\text { spinulosensoris, } \\
\text { Eumunida sp., } \\
\text { Galathea spp., Munida } \\
\text { spp., Galatheidae } \\
\text { indet., Homola } \\
\text { orientalis, Homolidae } \\
\text { indet., Ethusa sp., } \\
\text { Cryptocnemus obolus, } \\
\text { Leucosiidae indet., } \\
\text { Merocryptus } \\
\text { lambriformis, } \\
\text { Macrocheira } \\
\text { kaempferi, Pugettia } \\
\text { minor, Oxypleurodon } \\
\text { stimpsoni, } \\
\text { Trachycarcinus } \\
\text { sagamiensis, Cancer } \\
\text { gibbosulus, Cancer } \\
\text { japonicus, Carcinoplax } \\
\text { surugensis, Medaeus } \\
\text { serratus, Xanthidae } \\
\text { ind. }\end{array}$ & & $\begin{array}{l}\text { Fujiwara et al., } \\
2007\end{array}$ \\
\hline Present day & $\begin{array}{l}\text { NW Pacific } \\
\text { (Peter the Great } \\
\text { Bay, East Sea, } \\
\text { Russia) }\end{array}$ & $30 \mathrm{~m}$ & Mysticete & $\begin{array}{l}\text { Amphipods, } \\
\text { Isopods }\end{array}$ & & & $\begin{array}{l}\text { Pavlyuk et al., } \\
2009\end{array}$ \\
\hline
\end{tabular}


PALAEO-ELECTRONICA.ORG

\begin{tabular}{|c|c|c|c|c|c|c|c|}
\hline \multirow{2}{*}{ Age } & \multirow{2}{*}{ Region } & \multirow{2}{*}{$\begin{array}{c}\text { Depth/ } \\
\text { Environmen } \\
t\end{array}$} & \multirow{2}{*}{$\begin{array}{l}\text { Cetacean } \\
\text { Taxon }\end{array}$} & \multicolumn{2}{|c|}{ Crustaceans } & \multirow{2}{*}{ Benthic foraminifers } & \multirow{2}{*}{ References } \\
\hline & & & & Other & Decapods & & \\
\hline Present day & $\begin{array}{l}\text { NE Pacific } \\
\text { Ocean (off } \\
\text { Vancouver } \\
\text { Island, British } \\
\text { Columbia) }\end{array}$ & $1288 \mathrm{~m}$ & Mysticete & $\begin{array}{l}\text { Amphipoda sp., } \\
\text { Munnopsidae sp., } \\
\text { Mysida sp. }\end{array}$ & $\begin{array}{l}\text { Paralomis multispina, } \\
\text { Pandalopsis ampla }\end{array}$ & & $\begin{array}{l}\text { Lundsten et al., } \\
2010 a\end{array}$ \\
\hline Present day & $\begin{array}{l}\text { Antarctic (Kemp } \\
\text { Caldera, East } \\
\text { Scotia Sea) }\end{array}$ & $\begin{array}{l}1444-1447 \\
\mathrm{~m}\end{array}$ & Mysticete & $\begin{array}{l}\text { Jaera tyleri, } \\
\text { Lysianassidae } \\
\text { indet., Ilyarachna } \\
\text { sp., Sericosura } \\
\text { sp. }\end{array}$ & Nematocarcinus sp. & & $\begin{array}{l}\text { Amon et al., } \\
2013 ; \\
\text { Linse et al. } 2014\end{array}$ \\
\hline Present day & $\begin{array}{l}\text { Antarctic } \\
\text { (continental } \\
\text { slope off Anvers } \\
\text { Island) }\end{array}$ & $1430 \mathrm{~m}$ & Mysticete & $\begin{array}{l}\text { Amphipoda } \\
\text { (unidentified) }\end{array}$ & Paralomis birsteini & & $\begin{array}{l}\text { Smith et al., } \\
2014\end{array}$ \\
\hline Present day & $\begin{array}{l}\text { SW Atlantic } \\
\text { (São Paulo } \\
\text { Ridge, off Brasil) }\end{array}$ & $4204 \mathrm{~m}$ & Mysticete & $\begin{array}{l}\text { Stephonyx sp., } \\
\text { Epicaridea sp., } \\
\text { Copepoda }\end{array}$ & Munidopsis spp. & & $\begin{array}{l}\text { Sumida et al., } \\
2016\end{array}$ \\
\hline
\end{tabular}




\section{APPENDIX 2.}

Alphabetical list of Foraminifera species found in WFE 1-3 at Bargiano.

\section{Planktonic species}

Globigerina bulloides d'Orbigny, 1826

Globigerina cariacoensis Rögl \& Bolli, 1973

Globigerinoides ruber d'Orbigny, 1839

Globigerinoides sacculifer Brady, 1877

Globorotalia inflata (d'Orbigny, 1839)

Orbulina universa d'Orbigny, 1839

Turborotalita quinqueloba (Natland, 1938)

\section{Benthic species}

Ammonia beccarii (Linnaeus, 1758)

Ammonia parkinsoniana (d'Orbigny, 1839)

Ammonia perlucida (Heron-Allen \& Earland, 1913)

Ammonia tepida (Cushman, 1926)

Asterigerinata mamilla (Williamson, 1858)

Bannerella gibbosa (d'Orbigny, 1826)
Bigenerina nodosaria d'Orbigny 1826

Bolivina spathulata (Williamson, 1858)

Bulimina marginata d'Orbigny, 1826

Bulimina spinata Cushman \& Campbell, 1935

Cancris auriculus (Fichtel \& Moll, 1798)

Cassidulina laevigata d'Orbigny, 1826

Heterolepa floridana (Cushman, 1918)

Lenticulina calcar (Linnaeus, 1758)

Lobatula lobatula (Walker \& Jacob, 1798)

Marginulinopsis costata (Batsch, 1791)

Melonis barleeanus (Williamson, 1858)

Nonionella turgida (Williamson, 1858)

Quinqueloculina seminula (Linnaeus, 1758)

Siphotextularia concava (Karrer, 1868)

Uvigerina mediterranea Hofker, 1932

Vaginulina striatissima Schrodt, 1890 


\section{APPENDIX 3.}

Description of morphological test character of Vaginulina cf. V. striatissima. (Figure 6, in the text).

Calcareous hyaline test, elongated, slender, and strongly compressed with a progressive enlargement from the basal chamber towards the apertural chamber. Prominent basal spine, generally well preserved, sometimes broken in the apical portion. Test covered by numerous well developed costae. The shape of the test is almost straight on one side and slightly curved on the other. The maximum size of the test is close to the opening and can reach as much as $1 \mathrm{~mm}$. The chambers, generally flattened, vary in number from eight to twelve (in larger specimens). Generally, the last two chambers are slightly inflated. The sutures between the chambers are usually difficult to visualize; a thin groove is evident in some specimens, usually between the last and third last chamber. The sutures are oblique, scarcely visible in the basal chambers, and become progressively more visible approaching the last chamber. The aperture is aligned with the straight edge and is eccentric and circular with a radiate edge.

The test is crossed for its entire length by rectilinear costae, often bifurcated and/or anastomosed, which are not interrupted by the sutures between chambers. The costae branch off from the upper part of the basal spine and appear to diverge into a herringbone pattern from the margin of the straight side, generating a thin flange-shaped projection (Figure 6.2-3). The costae crossing the last chamber converge in the radiate opening (Figure $6.8,6.11)$. A smooth or thinly costate inclined surface connects the top of the last chamber with the aperture.

Dimensions. Maximum lengths are between 4.0$4.5 \mathrm{~mm}$ with a minimum of $2 \mathrm{~mm}$ in broken specimens missing the last chamber. The width of the apertural chamber is generally less than one milli- meter; the width of the aperture is approximately $0.1 \mathrm{~mm}$.

Type locality. Whale-fall sites at Bargiano and Montemoro (see Monaco et al. 2014), southwestern Umbria, Allerona, Central Italy.

Type levels. Early Pleistocene, Calabrian, clay marine deposits of Chiani-Tevere Unit (Baldanza et al. 2013, 2014).

Observations. The morphology of the test, which deviates from the characteristics of Vaginulina striatissima (originally drawn by Schrodt, 1890, plate 21, figure 9a-b, Ellis and Messina, 1940-2006) leads us to hypothesize that modifications in the costae and spine of these foraminifera were induced by the soft clay substrate and a high availability of nutrients that stimulated reproduction. The specimens found in the CFT section, compared to those found in Sections S1-S4, show differences in length of the test and in number of costae (radiating from basal spine to last chamber), which become thinner and more anastomized (Figure 6.6-6.7, 6.9, 6.12).

The development in our specimens of costae and basal spine may fall within the specific variability of the taxon, though we do not exclude that the taxon we identified as Vaginulina cf. V. striatissima may be included into a new species, the origin of which may be closely linked to the peculiarities of the living environment.

Notes. The specimens figured in Ellis and Messina (1940-2006) as Vaginulina striata d'Orbigny, 1826 (figs. 36, 58) and Vaginulina striatissima Schrodt, 1890 (figs. 9a-9b) are drawings: d'Orbigny and Schrodt both reported all the morphological characters described in our specimens (test shape, aperture shape and position, costae, and basal spine), but not all together. 


\section{APPENDIX 4.}

Morphology of specimens attributed to Albaidaplax ispalensis Garassino, Pasini and Castro, 2013 (Figure 7.1, in the text).

Superfamily GONOPLACOIDEA MacLeay, 1838

Family GONEPLACIDAE MacLeay, 1838

Subfamily GONEPLACINAE MacLeay, 1838

Genus ALBAIDAPLAX Garassino, Pasini and

Castro, 2013

Type species. Albaidaplax ispalensis Garassino, Pasini and Castro, 2013, by monotypy.

Included species. Albaidaplax ispalensis Garassino, Pasini and Castro, 2013.

Albaidaplax ispalensis Garassino, Pasini and Castro, 2013

Figure 7.1

v. 1998 Goneplax gulderi Bachmayer; Mayoral et al., p. 508, 509, fig. 2 (5).

v. 1948 Goneplax cf. saccoi [sic]; Vía, p. 146, fig. 6.; Solé and Vía, 1989: 34.

v. 1989 Goneplax cf. saccoi [sic]; Solé and Vía, p. 34.

$V^{*} 2013$ Albaidaplax ispalensis Garassino, Pasini and Castro, p. 362, 363, fig. 4.

v. 2014 Albaidaplax ispalensis Garassino, Pasini and Castro; Pasini et al., p. 252, fig. 8A.

Carapace rectangular, slightly wider than long, straight front wide as the orbits; wide orbits expanded distally with a short, triangular forwarddirected tooth on outer orbital angle; supraorbital margins gently convex; anterolateral margins slightly convex with a smooth, short, barely distinct tooth; posterolateral margins slightly narrowing posteriorly; straight posterior margin; smooth dorsal surface of carapace; weak transverse ridges moderately convex; dorsal carapace without clear indication of regions; stout chelipeds with moderately long and large merus; subtriangular carpus spineless; palm smooth dorsally; dactylus and index nearly as long as the propodus; unarmed occlusal margins; ambulatory legs elongate, flattened, and slender.

Material and measurements. Five specimens in dorsal view, housed in the Museo di Allerona (MUAL) (MUAL 3 - carapace length: $28 \mathrm{~mm}$; carapace width: $31 \mathrm{~mm}$. MUAL 6 - carapace length: 22 $\mathrm{mm}$; carapace width: $25 \mathrm{~mm}$. MUAL 7 - carapace length: $15 \mathrm{~mm}$; carapace width: $18 \mathrm{~mm}$. MUAL 8 carapace length: $25 \mathrm{~mm}$; carapace width: $28 \mathrm{~mm}$. MUAL 9 - carapace length: $28 \mathrm{~mm}$; carapace width: $31 \mathrm{~mm}$ ). 


\section{APPENDIX 5.}

Morphology of specimens attributed to Chlinocephalus demissifrons Ristori, 1886 (Figure 7.2, 7.3 , in the text).

Family EURYPLACIDAE Stimpson, 1871

Genus CHLINOCEPHALUS Ristori, 1886

Type species. Chlinocephalus demissifrons Ristori, 1886 , by monotypy.

Included species. Chlinocephalus demissifrons Ristori, 1886.

Note. Schweitzer et al. (2010) erroneously reported two species as belonging to this genus: $C$. demissifrons Ristori, 1886, and C. subovalis (Ristori, 1886). Ristori (1886) described Chlinocephalus based on the type and sole species, $C$. demissifrons. No species named subovalis is reported in the original text. The genus is therefore monotypic, as correctly reported by Karasawa and Kato (2003).

Chlinocephalus demissifrons Ristori, 1886

Figures 7.2, 7.3

V*1886 Chlinocephalus demissifrons Ristori, p. 101103, pl. 2, figs. 5,6 .

v. 2003 Chlinocephalus demissifrons Ristori; Karasawa and Kato, tab. 5.

v. 2004 Chlinocephalus demissifrons Ristori; Garassino et al., p. 275-278, figs. 15, 16.

v. 2013 Chlinocephalus demissifrons Ristori; Pasini and Garassino, p. 321, fig. 2.

Suboval carapace wider than long, convex dorsally and nearly smooth; wide fronto-orbital margin extends over the orbits; frontal straight margin with weak median frontal incision and two distinct oblique pre-orbital incisions laterally; concave deep wide orbits obliquely directed to the frontal margin, with a small short median incision; supraorbital margins concave with a short, triangular point at the extremities; short anterolateral margins with two sharp, pointed, triangular spines, the first close to the extraorbital tooth, on the hepatic margin, the second on the epibranchial margin at the level of a smooth dorsal transverse carina that is slightly curved and convex in the middle; posterolateral margins convex wide, crossed by a second transverse dorsal carina, nearly straight medially; wide posterior margin gently convex; carapace dorsal region not distinct, slightly depressed between the two transverse ridges, and posteriorly, behind the second ridge toward the posterior margin; postfrontal region depressed slightly below level of remainder of carapace; suboval wide cardiac region poorly marked; dorsal carapace ornamented with sparse pits or coarse granulations, notably along the transverse ridges; P1 well developed, with elongate merus; globular carpus with a strong spine on inner distal margin; robust chelae with flattened inner palm; elongate, pointed, and armed dactylus and index, curved, converging distally; granulated chelipeds, possibly unequal (Ionger in male); elongate, flattened, and slender ambulatory legs, ovoid in transverse section; male thoracic sternum subcircular, with finely punctulate surface; sternites 5-7 petaloid in shape, sternite 8 reduced, poorly preserved; male pleon narrow, slender, T-shaped, with six movable subtrapezoidal somites plus telson, narrowly triangular; somites and telson slightly inflated longitudinally forming a median smooth, rounded, tubercle-like protuberance; wide trapezoidal s3 covering space behind P5 coxae; s4-s6 shorter, slightly narrowing to the triangular telson, rounded distally.

Material and measurements. Ten complete and incomplete specimens; we selected three specimens in dorsal and ventral view, slightly compressed dorso-ventrally (MUAL2: ventral view; MUAL10 - carapace length: $25 \mathrm{~mm}$; carapace width: $32 \mathrm{~mm}$. MUAL11-12 - carapace length: 32 $\mathrm{mm}$; carapace width: $39 \mathrm{~mm}$ ). 